\title{
Impactos Econômicos do Aumento das Exportações Brasileiras de Produtos Agrícolas e Agroindustriais para Diferentes Destinos ${ }^{1,2}$
}

\author{
Fernando Salgueiro Perobelli ${ }^{3}$, Admir Antonio Betarelli Junior ${ }^{4}$, \\ Vinicius de Almeida Vale ${ }^{5}$ e Ramon Goulart Cunha ${ }^{6}$
}

Resumo: As atividades exportadoras do agronegócio brasileiro são consideradas estratégicas para a política comercial brasileira, pois além de contribuir para o superavit comercial e para o crescimento econômico no País, essas atividades revelam um alto grau de inserção no comércio internacional, tanto pelo número de mercados tradicionais existentes quanto pela capacidade de explorar novos mercados potenciais. Nesse sentido, este trabalho analisa os prováveis efeitos de uma expansão da demanda externa por produtos agrícolas e agroindustriais em alguns mercados tradicionais e potenciais, utilizando um modelo de Equilíbrio Geral Computável (EGC) para o Brasil, LATES-BR, calibrado para 2011. As projeções geradas permitem realizar uma avaliação quantitativa da importância relativa dos mercados tradicionais e potenciais do agronegócio brasileiro e contribuem para o debate em curso do Plano Nacional de Exportações (PNE). O tamanho dos impactos dos potenciais mercados, principalmente em países da América do Sul, quando comparados com os mercados tradicionais, no caso os Estados Unidos, é bem menor. Entretanto, conforme discutido no trabalho, a questão mais importante não é o tamanho do impacto, mas sim o movimento em termos macroeconômicos e os resultados de comércio, ou seja, o potencial de explorar novos mercados como alternativa de aumento da participação brasileira no comércio internacional.

Palavras-chaves: Agronegócio, comércio internacional, modelos de equilíbrio geral computável.

1. Os autores agradecem o financiamento do CNPq, Capes e Fapemig para elaboração deste trabalho.

2. Data de submissão: 26 de novembro de 2015. Data de aceite: 23 de abril de 2017.

3. Universidade Federal de Juiz de Fora. Juiz de Fora, Minas Gerais, Brasil. E-mail: fernando.perobelli@ufjf.edu.br

4. Universidade Federal de Juiz de Fora. Juiz de Fora, Minas Gerais, Brasil. E-mail: admir.betarelli@ufjf.edu.br

5. Universidade Federal de Juiz de Fora. Juiz de Fora, Minas Gerais, Brasil. E-mail: vinicius.a.vale@gmail.com

6. Universidade Federal de Juiz de Fora. Juiz de Fora, Minas Gerais, Brasil. E-mail: ramongcunha@hotmail.com 
Abstract: Brazilian export agribusiness activities are considered strategic to the Brazilian trade policy because, besides the contribution to the trade surplus and economic growth in the country, these activities reveal a high degree of insertion in the international trade, both by the number of existing traditional markets and by the capacity to explore new potential markets. Thus, this study analyzes the probable effects of an external demand expansion for agricultural and agroindustrial products in some traditional and potential market, using a Computable General Equilibrium (CGE) model for Brazil, LATES-BR, calibrated to 2011. The projections allow us to do a quantitative assessment of the relative importance of the Brazilian agribusiness traditional and potential markets and it contributes to the ongoing debate of the National Export Plan (PNE). The impacts size of the potential markets, especially countries in South America, when compared with traditional markets, such as the United States of America, is much lower. However, as discussed in our study, the most important issue is not the impact size, but the movement in macroeconomic terms and the trade results, i.e. the potential to explore new markets as an alternative to increase the Brazilian share in the international trade.

Key-words: Agribusiness, international trade, computable general equilibrium models.

DOI - http://dx.doi.org/10.1590/1234-56781806-94790550208

Classificação JEL: Q17, Q18, C68.

\section{Introdução}

Após o enfraquecimento da demanda externa e o fim do ciclo de preços elevados das commodities em meados de 2008, políticas de incentivos às exportações brasileiras têm sido foco do governo federal. Em conjunto, essas medidas foram estabelecidas para reverter o deficit comercial, estimular o crescimento econômico e o nível de competitividade do País, bem como diversificar a composição da pauta exportadora pelo aumento da participação dos produtos manufatureiros. Especialmente no Plano Brasil Maior 2011-2014 (PBM) - (BRASIL, 2011), a desoneração das exportações foi implementada para conter o aumento das importações e a queda de competitividade do setor industrial, cuja conjuntura sinalizava para uma desindustrialização da economia. Como o plano englobava majoritariamente medidas de estímulos ao mercado interno, nele não foi realizado qualquer diagnóstico sobre os mercados potencialmente favoráveis para as exportações brasileiras.

Esse diagnóstico foi feito pelo recente Plano Nacional de Exportações 2015-2018 (PNE), lançado pelo governo federal em junho de 2015. O PNE é parte integrante da política comercial brasileira e visa articular as características da pauta exportadora do País com o comportamento dos mercados internacionais (BRASIL, 2015b). Além de uma análise de retomada e manutenção sobre os mercados tradicionais e cativos, o plano avalia a inserção da produção doméstica em novos mercados externos. Nesse diagnóstico estão os mercados listados majoritariamente para os produtos do agronegócio brasileiro, cujo volume exportado do setor cresceu $230 \%$ entre 2000 e 2013, atingindo aproximadamente US\$ 100 bilhões no final de 2013, conforme dados do Centro de Estudos Avançados em Economia Aplicada (CEPEA- ESALQ/USP). O setor do agronegócio engloba bens não processados como os bens agrícolas e agropecuários processados ${ }^{7}$ e, desde 2007, sempre foi o principal responsável pelo saldo positivo da balança comercial, fechando em 2013 em um montante de US\$ 83 bilhões. A China, os Estados Unidos (EUA) e os Países Baixos têm sido, ao longo dos últimos anos, os principais destinos das exportações brasileiras do agronegócio (BARROS e ADAMI, 2012; BARROS et al., 2013; BARROS et al., 2014).

\footnotetext{
7. Agronegócio engloba tanto as atividades realizadas pelos produtores rurais (i.e., setores agrícola e pecuário, que produzem grãos, cereais, legumes, verduras, frutas, animais de corte), quanto aquelas realizadas por representantes da indústria (e.g., produção de biocombustíveis, fertilizantes, tecidos, processamento de alimentos e bebidas, entre outros).
} 
Alguns dos mercados classificados pelo PNE com grande potencialidade de inserção dos produtos do agronegócio, também são evidenciados pelo Ministério da Agricultura, Pecuária e Abastecimento - Mapa (BRASIL, 2015a), instituição responsável pelo posicionamento do País nas negociações agrícolas internacionais, nos âmbitos multilateral, regional e bilateral. O Mapa, por exemplo, aponta para a reabertura das exportações de carne bovina desossada e carne suína no acordo comercial que ocorre no mercado da África do Sul, cuja projeção é elevar as vendas externas desses respectivos produtos para aproximadamente US\$ 7 milhões e US\$12 milhões anuais. Do mesmo modo, segundo informações do Mapa, o Brasil negocia acordos comerciais para algumas exportações agrícolas com novos mercados da América do Sul e Central (e.g., Cuba, Chile, Colômbia, Equador, México e Peru).

Tanto os mercados tradicionais quanto esses novos mercados (ou pouco explorados) conferem às atividades exportadoras do agronegócio a possibilidade de ganhos de produtividade e escala, ampliando, por conseguinte, o seu nível competitivo no mercado internacional. Além disso, a ampliação da demanda externa do setor estimula outras atividades no mercado interno brasileiro, encadeando uma série de efeitos multiplicadores e contribuindo positivamente para os resultados macroeconômicos e setoriais no País. Trata-se de um setor que abrange $23 \%$ do Valor Adicionado (VA) da economia brasileira (valores constantes de 2013), de acordo com as informações do Centro de Estudos Avançados em Economia Aplicada (Cepea).

Entretanto, por vezes, independentemente do seu nível de competitividade, o desempenho exportador do agronegócio é determinado pelas políticas protecionistas, reduções de barreiras comerciais e pelos acordos bilaterais ou multilaterais realizados entre os mercados externos. A criação de um sistema de comércio multilateral pós-guerra, por exemplo, estimulou a comercialização e produção interna entre os seus países membros por medidas de redução ou isenção dos impostos e/ou tarifas alfandegá- rias. Após o desenvolvimento dos blocos comerciais, instituições como as Nações Unidas (ONU), o Banco Internacional para Reconstrução e Desenvolvimento (BIRD) e o Fundo Monetário Internacional (FMI) foram criados, o que acabou refletindo a nova ordem internacional (SILVA, 2000; OMC, 2011). Entretanto, o comércio internacional de produtos agrícolas sempre foi marcado por controversas ou conflitos de interesses dentro do debate de políticas protecionistas. São práticas que inferem a liberalização comercial, previamente definida nos acordos multilaterais de comércio. Geralmente, países mais desenvolvidos, como os Estados Unidos e alguns europeus, procuram sustentar as suas atividades agrícolas por questões políticas, principalmente naquelas que revelam desvantagens absolutas de custos.

Esse cenário evidencia que a participação dos governos no processo produtivo agrícola e no comércio tem crescido, com o intuito de aumentar e sustentar a renda agrícola, evitando as grandes flutuações de preços no mercado internacional, além de desenvolver autossuficiência básica na produção. O interesse ofensivo do Brasil nesse setor, com vistas a maior liberalização comercial, confronta muitas das vezes com o protecionismo de alguns países do Mercosul ${ }^{8}$, que previamente acordaram o livre comércio. Similarmente, o Brasil enfrenta as mesmas práticas protecionistas nos acordos em processo de negociação com a União Europeia, Israel, Índia e África do Sul.

Nesse mote de pesquisa, a contribuição do presente trabalho está em identificar quais potenciais acordos/políticas podem ser eficazes em termos de ganhos econômicos e quais podem ser prejudiciais ou menos eficazes. Embora o diagnóstico do PNE represente um avanço para delinear estratégias da política comercial brasileira, o mesmo não realiza uma análise quantitativa sobre como são transmitidos os efeitos econômicos oriundos especialmente de expansões das exportações agroindustriais no Brasil, cuja lacuna este estudo pretende cobrir. Entretanto, essas

8. Mercado Comum do Sul, o qual o Brasil faz parte desde a sua criação, em 1991. 
repercussões econômicas dependem do entendimento, mesmo que breve, das características produtivas na economia brasileira. Assim, o principal objetivo do estudo é analisar os prováveis desdobramentos macroeconômicos e setoriais de curto prazo das exportações de commodities agrícolas e de produtos agroindustriais (bens processados) sobre a economia brasileira. Nessas análises são considerados dois cenários para a atividade econômica do País. No primeiro, choques favoráveis dessas vendas externas não comprometem a oferta de todas as atividades do sistema produtivo brasileiro, especialmente aquela destinada para os diversos mercados internacionais. Já no segundo cenário, admite-se que as atividades econômicas procuram elevar suas receitas, direcionando a oferta de seus produtos para o mercado com preço mais atrativo.

Espera-se também que as mudanças independentes nas exportações dos produtos agrícolas e processados para certos parceiros comerciais provoquem estímulos de crescimento econômico, com efeitos multiplicadores transmitidos em todo o sistema produtivo brasileiro. Portanto, os resultados projetados devem ser de grande interesse para o debate em curso da política comercial brasileira do Ministério do Desenvolvimento, Indústria e Comércio Exterior (MDIC), por identificar a importância relativa dos mercados tradicionais e potenciais das atividades exportadoras do agronegócio brasileiro, bem como pelas nuances em que estão envolvidos o comércio de bens agrícolas (e.g., protecionismo, acordos gerais de comércio, acordos bilaterais, entre outros).

A análise das exportações do agronegócio procede a partir de um modelo estático de Equilíbrio Geral Computável (EGC), desenvolvido para o Brasil em 2011. Modelos de EGC reconhecem os canais intersetoriais de um sistema econômico e vêm se tornando uma ferramenta de auxílio para avaliação quantitativa de políticas econômicas, fornecendo projeções gerais, tanto no âmbito micro como no macroeconômico (DIXON e RIMMER, 2002). Na sua especificação teórica e estrutura de dados, o modelo de EGC utilizado nesse trabalho apresenta uma série de inovações. Primeiro, o modelo é calibrado com dados do Novo Sistema de Contas Nacionais do Instituto Brasileiro de Geografia e Estatística (IBGE), reconhecendo 68 atividades econômicas e 128 produtos. Deste número de produtos, 31 são do agronegócio, sendo 15 commodities agrícolas e 16 produtos agroindustriais (bens processados). Segundo, a estrutura básica e certas equações comportamentais do modelo foram alteradas em conformidade com a desagregação do vetor de exportações, englobando os principais e os potenciais parceiros do Brasil.

Cabe ressaltar que há na literatura um grande número de estudos que avaliam os impactos de distintas políticas sobre o setor agropecuário brasileiro, porém, a maioria desses trabalhos não tem como preocupação fazer avaliações comparativas do cenário de projeção do agronegócio e das políticas comerciais brasileiras, em suas diversas nuances. Há outros na literatura que versam sobre o tema agronegócio e fazem uso da modelagem de insumo-produto e EGC. O trabalho seminal de Guilhoto (1995), por exemplo, objetiva a construção de um modelo de EGC para o Planejamento e Análise de Políticas Agrícolas (Papa) para a economia brasileira. Posteriormente, Ferreira Filho (1997) também calibra um modelo multissetorial de EGC para avaliar a política agrícola brasileira e, de forma mais específica, os efeitos de choques externos do início da década de 1980 sobre a economia brasileira. Em um outro trabalho, Ferreira Filho (1999) avalia os efeitos do processo de liberalização comercial e de constituição do Mercosul sobre a economia brasileira, com ênfase nos setores produtivos agrícolas e agroindustriais. Já Figueiredo et al. (2010) avaliam os impactos dos subsídios norte-americanos, concedidos entre 2002 e 2007 sobre o crescimento do agronegócio brasileiro. Recentemente, Gurgel (2014) estima os impactos de políticas comerciais e setoriais capazes de afetar o agronegócio brasileiro. Ademais, têm-se outras importantes contribuições no que tange a avaliação dos impactos de políticas comerciais sobre o setor (e.g., FERREIRA FILHO, 1999; CYPRIANO e TEIXEIRA, 2003; GURGEL e CAMPOS, 2003; GURGEL, 2006; GURGEL et 
al., 2009). Cardoso e Teixeira (2013) investigaram o efeito da política agrícola sobre o desenvolvimento do agronegócio nas diferentes regiões do Brasil. Os impactos da política tributária sobre o consumo de alimentos e a agropecuária, por sua vez, foram investigados por Santos e Ferreira Filho (2007).

Além dessa seção introdutória, esse trabalho se organiza em mais três seções. A segunda descreve a metodologia, as hipóteses de curto prazo e as simulações. A terceira seção traz os resultados projetados e a decomposição do Produto Interno Bruto (PIB), bem como avaliações de quais as atividades econômicas que se beneficiaram e quais foram prejudicadas em termos de produção e emprego. Por fim, a quarta seção apresenta as considerações finais da pesquisa, salientando os principais resultados, contribuições e implicações em termos de política comercial.

\section{Metodologia e simulações}

A análise de impactos nacionais e setoriais das exportações de produtos agrícolas e agroindustriais é feita por meio de simulações em um modelo de Equilíbrio Geral Computável (EGC), denominado LATES-BR (Links And Transmissions on Exports of the agribusinesS in Brazil). Cabe ressaltar que o LATES-BR é uma extensão do modelo BIM-RD (Brazilian Intersectoral Model with Recursive Dynamic), em que a estrutura teórica, processo de calibragem e construção do núcleo de dados estão em Betarelli Junior, Perobelli e Vale (2015b). ${ }^{9}$

Em suas dimensões, o modelo LATES-BR reconhece 68 setores produtivos, que produzem um ou mais dos 128 produtos, três fatores de produção (trabalho, capital e terra), e cinco tipos de usuários finais, divididos entre investidores pro-

9. A presente seção apresenta de forma simplificada o processo de especificação teórica, calibragem e construção do modelo, tendo como foco principal o problema de pesquisa aqui proposto. Para uma descrição detalhada do modelo BIM-RD, incluindo descrição das principais equações comportamentais do modelo e processo de calibragem, ver Betarelli Junior, Perobelli e Vale (2015b). dutivos, famílias, governo, consumidores externos (ou destinos) e estoques. Além disso, com o papel de facilitar os fluxos dos 128 produtos entre pontos de produção até os usuários domésticos, existem quatro tipos de margens: Comércio e reparação de veículos; Comércio por atacado e a varejo, exceto veículos automotores; Transporte terrestre de carga; e Transporte aquaviário. Os custos de serviços de margens, junto aos três impostos indiretos (IPI, ICMS e Outros), representam as diferenças entre os preços do comprador (pago pelos usuários) e os preços básicos (recebidos por produtores e importadores). Os impostos incidentes sobre os serviços de margens são tratados como pagos pelos setores de margens no modelo, o que garante a igualdade entre o preço de custo e preço básico com respeito aos serviços relacionados às margens. Ademais, no valor adicionado de cada setor, além das remunerações dos fatores de produção, há um agregado de impostos sobre a produção.

Vale ressaltar que o núcleo da base de dados do modelo consiste na Matriz de Insumo-Produto (MIP) de 2011 para Brasil, estimada por Betarelli Junior, Perobelli e Vale (2015a) a partir das Tabelas de Recursos e Usos (TRUs) da nova série do Sistema de Contas Nacionais (SCN) disponibilizadas pelo Instituto Brasileiro de Geografia e Estatística (IBGE, 2015). Conforme detalhado pelos autores, o método de estimação adotado consiste na adequação conjunta dos procedimentos descritos em IBGE (2008), Guilhoto e Sesso Filho $(2005,2010)$ e Martinez $(2014 a, 2014 b$, 2015). ${ }^{10}$

Entretanto, diferente da MIP estimada e do modelo BIM-RD, o modelo LATES-BR, utilizado no presente estudo, apresenta as exportações desagregadas para 18 países e 2 regiões, a saber: África do Sul, Arábia Saudita, Argentina, Chile, China, Colômbia, Coreia do Sul, Cuba, Equador, Estados Unidos, Índia, Japão, México,

10. Para mais detalhes do procedimento de estimação da MIP, bem como uma análise inicial das interdependências e encadeamentos produtivos do sistema brasileiro no período, recomenda-se a leitura de Betarelli Junior, Perobelli e Vale (2015a). 
Paraguai, Peru, Rússia, Uruguai, Venezuela, União Europeia e restante do mundo. O critério de desagregação ocorreu mediante a identificação e avaliação de quais seriam os principais e potenciais destinos das demandas externas pelos produtos agrícolas e agroindustriais no Brasil. Para tanto, utilizou-se informações da Secretaria de Comércio Exterior (Secex) do Ministério do Desenvolvimento, Indústria e Comércio Exterior (MDIC) e do Ministério da Agricultura, Pecuária e Abastecimento (Mapa). Assim, a composição média das exportações por esses destinos identificados no modelo LATES-BR pode ser observada na Figura 1. Por meio dela, é possível observar a participação relativa das exportações de cada um dos países divididas em produtos agrícolas, processados (agroindustriais) e outros produtos (barras empilhadas), bem como volume total exportado em R \$ bilhões por destino (marcador/ círculo branco).

Há uma semelhança entre os destinos mais representativos na pauta exportadora de pro- dutos agrícolas e agroindustriais. Ou melhor, as exportações de ambos os bens são majoritariamente destinadas para alguns dos países orientais, latino-americanos, bem como a região europeia. Na composição das vendas externas de produtos agroindustriais destacam-se a Arábia Saudita (49,59\%), Cuba (49,93\%), União Europeia $(16,71 \%)$, Japão $(17,90 \%)$, Rússia $(78,58 \%)$, Venezuela $(32,43 \%)$ e restante do mundo $(31,56 \%)$. Já nas exportações de commodities agrícolas, predominam destinos como Arábia Saudita $(15,93 \%)$, China $(22,11 \%)$, Cuba $(13,37 \%)$, União Europeia $(14,63 \%)$, Japão $(11,81 \%)$, Venezuela $(13,97 \%)$ e restante do mundo $(8,73 \%)$. A identificação destes destinos mais proeminentes na estrutura dessas exportações favorece a interpretação dos resultados projetados, especialmente neste trabalho. Por exemplo, espera-se que uma expansão na demanda da União Europeia sobre os produtos agrícolas e agroindustriais estimulem a atividade econômica do Brasil, pois além de induzir diretamente a produção destes respectivos produtos,

Figura 1. Participação relativa dos consumidores externos no modelo LATES-BR

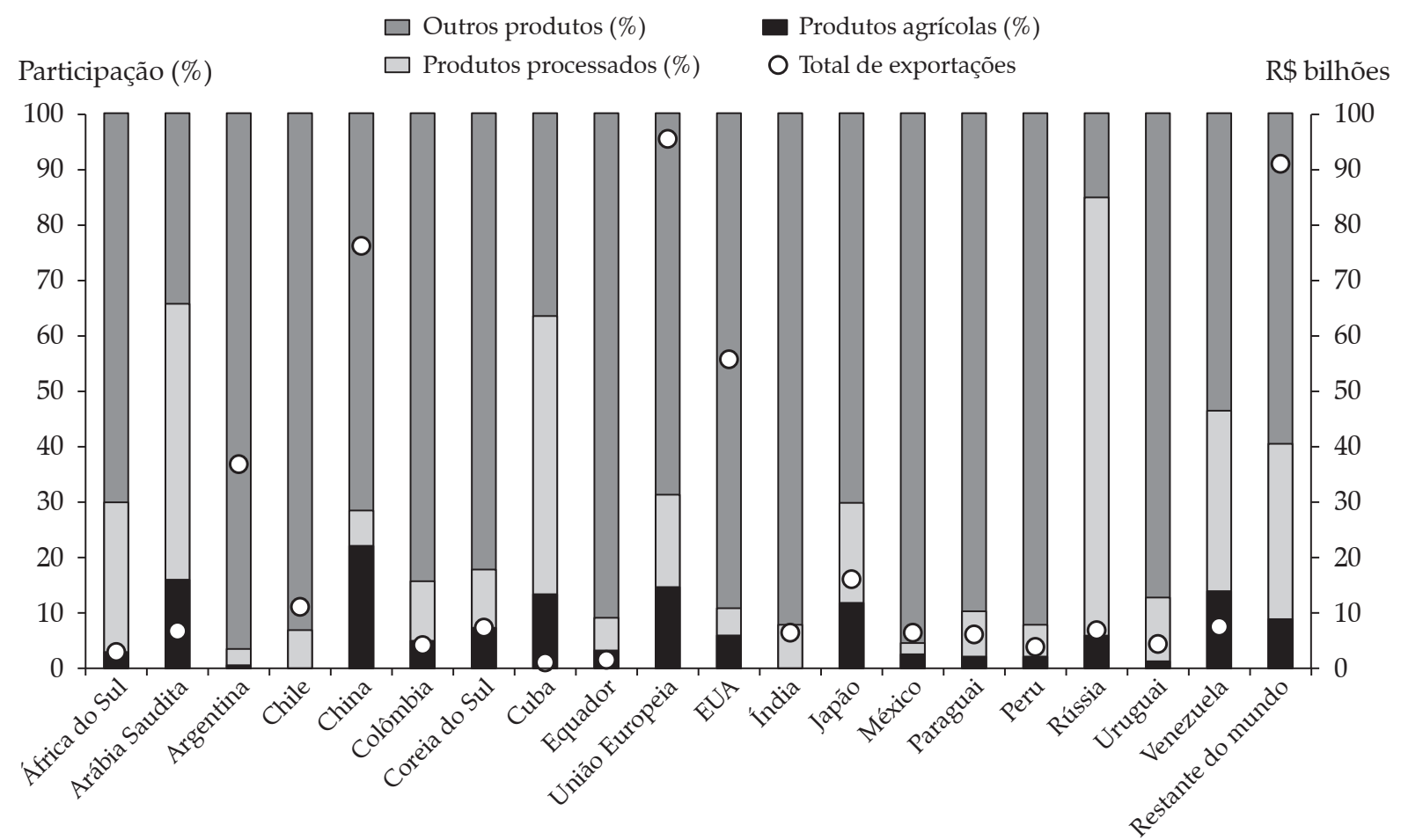

Fonte: Elaboração própria a partir de dados do MDIC. 
estimularia indiretamente outros mercados pelas transmissões nas interações setoriais do modelo. Em outras palavras, efeitos diretos e indiretos através do encadeamento produtivo dentro da economia brasileira.

Apesar da desagregação do vetor de exportações, assim como o modelo BIM-RD, o modelo LATES-BR acompanha a tradição australiana Monash e Orani (DIXON et al., 1982), do tipo Johansen (1960), em que a estrutura matemática representa-se por um conjunto de equações linearizadas e as soluções são alcançadas na forma de taxa de crescimento. Como padrão em modelos de EGC nacionais, a sua estrutura central é formada por blocos de equações que determinam relações de oferta e demanda, derivadas das hipóteses do sistema walrasiano de equilíbrio geral de Arrow-Debreu (1954). Nesse sistema, a tecnologia de produção revela retornos constantes de escala, produtores obtêm somente lucro econômico zero e os mercados exibem estrutura de concorrência perfeita (HORRIDGE, 2000; DIXON e RIMMER, 2002).

A função de produção dos setores multiprodutos divide-se entre a composição de produto produzido e a demanda dos insumos intermediários e dos fatores de produção, em que ambas as partes estão interligadas pelo nível de atividade setorial. A partir de uma função de agregação CET (Constant Elasticity of Transformation), os setores multiprodutos transformam o seu composto de oferta produzindo bens com preços relativamente mais altos; e em seguida são destinados à exportação e ao mercado nacional. Em razão dessa propriedade de maximização de receita, os setores multiprodutos, como a agricultura e a pecuária, podem redirecionar suas ofertas para o mercado relativamente mais favorável, como atender mais o mercado externo em detrimento do mercado nacional. Por outro lado, todos os setores (monoprodutos e multiprodutos) minimizam os custos de produção demandando insumos intermediários e fatores primários em proporções diretas (tecnologia Leontief). Na composição de cada insumo intermediário, a razão entre as parcelas de compras domésticas e importadas é função apenas dos preços relativos das duas origens, sem também haver uma completa substituição de uma fonte por outra. Essa substituição imperfeita consiste na hipótese de Armington (1969), controlada por uma tecnologia CES (Constant Elasticity of Substitution). Na composição do fator primário também existe uma substituição imperfeita via preço por uma função CES entre capital, trabalho e terra. Assim, em virtude dessas especificações características na função de produção de cada setor, tanto alterações no produto quanto nos preços relativos levam às mudanças nas demandas dos fatores e insumos de produção. Embora a especificação teórica seja idêntica para todos os setores, as elasticidades de substituições e as proporções de insumos e fatores primários podem variar entre os mesmos.

De forma similar aos produtores, os investidores produtivos minimizam os seus custos combinando os insumos para formar as unidades de capital, sujeitos a uma dada tecnologia. A partir de uma tecnologia Leontief, as demandas dos insumos são proporcionais à variação da quantidade de capital criada. Em cada composto, uma função CES é novamente utilizada na combinação entre os insumos domésticos e os importados. Não obstante, nenhum fator primário é usado diretamente como insumo na formação do capital. Tal uso é reconhecido via insumos no setor da construção civil ou outros setores relacionados à formação bruta de capital fixo.

Por seu turno, as famílias determinam uma composição ótima das suas "cestas" de consumo a partir de um sistema linear de gastos (LES), sujeito a uma restrição orçamentária. A LES divide o consumo total do composto do bem em duas partes: uma de subsistência (ou mínimo) e outra de luxo (ou supernumerário). Nessa divisão, é reservada uma parcela fixa do gasto em subsistência e uma parcela residual em "gasto de luxo", o que permite que variações na renda causem diferentes mudanças no consumo dos produtos. Nessa estrutura, a demanda por cada bem é uma função positiva do total de gastos de luxo 
e do número da família"11 (exógena) e negativa do preço do consumidor. Para cada bem na cesta de consumo das famílias existe uma tecnologia CES que controla a substituição imperfeita por preços relativos entre origem doméstica e importada.

Em relação à demanda do governo, existem duas formas de tratamento. Primeiro, pode-se associá-la às mudanças do consumo privado real. Nesse caso, por exemplo, supõe que os efeitos de uma política de bem-estar afetam igualmente os setores privados e públicos no longo prazo. Ou, alternativamente, pode-se adotar a hipótese que os gastos do governo são acomodados dentro de uma política de restrição orçamentária. Já os estoques se acumulam de acordo com a variação da produção.

Neste trabalho, é de particular interesse a especificação teórica do comércio externo. Por essa razão, tonar-se oportuno apresentar a equação comportamental (em forma percentual) da demanda externa. Para tanto, inicialmente adota-se a hipótese de economia pequena no comércio internacional, de maneira que mudanças no comércio externo brasileiro não influenciam os preços internacionais. De acordo com a equação (1), a demanda externa no destino $f$ por produto nacional $c\left(x_{4}^{c f}\right)$ é função do preço médio em moeda externa $\left(p_{4}^{c f}-\Phi\right)$ e das variáveis de deslocamento $\left(F_{4 P}^{c f}, F_{4 x}^{c f}\right)$ :

$$
x_{4}^{c f}-F_{4 x}^{c f}=-\sigma_{E X}^{c}\left(p_{4}^{c f}-\Phi-F_{4 P}^{c f}\right)
$$

em que $\Phi$ é a mudança percentual na taxa cambial (numerário do modelo, exógeno); $\sigma_{E X}^{c}$ é um parâmetro de elasticidade-preço constante de demanda. As demandas de exportação são funções decrescentes de $\left(p_{4}^{c f}-\Phi\right)$ e, usualmente, as variáveis de deslocamento são exógenas. Mantidas exógenas, estas variáveis permitem simular os efeitos dos movimentos nas curvas de demanda externa para um particular bem doméstico e para um particular mercado exportador $f$. Alternativamente, deslocamentos endógenos em $F_{4 P}^{c f}$ e $F_{4 x}^{c f}$ podem ser usados para acomodar

11. Nos resultados projetados nessa pesquisa pelo modelo LATES-BR, essa variável é exógena. previsões exógenas para um particular mercado exportador. ${ }^{12}$

Nesse estudo, a variável $F_{4 x}^{c f}$ foi mantida endógena para aplicar choques exógenos na variável $x_{4}^{c f}$ em dois grupos de produtos, quais sejam: produtos agrícolas e produtos agroindustriais (processados). Portanto, no ambiente econômico do modelo para essa pesquisa há uma troca entre a variável de deslocamento $\left(F_{4 x}^{c f}\right)$ e a demanda externa $\left(x_{4}^{c f}\right)$. Essa troca permite o tratamento do primeiro cenário, como já mencionado na introdução. Ou melhor, a mesma possibilita que os choques favoráveis nas vendas externas dos dois grupos de produtos do agronegócio não afetem negativamente a participação das outras atividades exportadoras nos diversos mercados internacionais. Assim, para manter constantes as vendas externas nos outros setores econômicos, os deslocamentos endógenos da curva de demanda $\left(F_{4 x}^{c f}\right)$ anulariam os efeitos negativos de uma eventual realocação da produção dentro do País. Por outro lado, já no segundo cenário, a variável $F_{4 x}^{c f}$ é mantida como exógena para que variável $x_{4}^{c f}$ flutue perante a ocorrência da realocação da produção dentro do País em certos produtos finais. A exceção desta regra ocorre somente aos dois grupos de produtos do agronegócio, justamente porque se procura aplicar os choques na mesma variável $\left(x_{4}^{c f}\right)$ com a possibilidade da realocação da produção dentro do País.

\subsection{Instrumentos e simulações}

A especificação teórica e o detalhamento do mercado externo na base de dados do modelo LATES-BR permite projetar consistentemente os efeitos econômicos de possíveis mudanças exógenas nas exportações agrícolas e agroindustriais

12. O subscrito " 4 " apresentado nas variáveis corresponde ao quarto tipo de demandante dos produtos no modelo LATES-BR, o mercado externo. Já os subscritos " $x$ " e " $P$ " nas varáveis $F_{4 x}^{c f}$ e $F_{4 p}^{c f}$, respectivamente, são utilizados para distinguir as duas variáveis de deslocamento. A primeira corresponde a um deslocamento na demanda externa $\left(x_{4}^{c f}\right)$, por isso o subscrito " $x$ ". A segunda, por sua vez, corresponde a um deslocamento no preço médio em moeda externa $\left(p_{4}^{c f}-\Phi\right)$, por isso, o subscrito " $P$ ". 
por parceiros comerciais. Dessa maneira, o propósito é simular um cenário de crescimento de $10 \%$ das exportações de ambos os tipos de produtos, aplicando choques individuais por destinos ${ }^{13}$ na variável de demanda por exportações $\left(x_{4}^{c f}\right)$. As simulações são homogêneas; porém, divididas em dois grandes grupos: a) commodities agrícolas e b) agroindustriais (i.e., bens agrícolas processados). Portanto, considerando-se os destinos das exportações de commodities agrícolas e produtos agroindustriais foram realizados 80 exercícios de simulação. Isso se deve ao fato de que, para cada grupo de simulação (commodities agrícolas e agroindustriais), têm-se dois cenários para avaliar a expansão das exportações brasileiras:

- Cenário 1: expansão das exportações sem realocação da produção dentro do País; e

- Cenário 2: expansão das exportações com realocação da produção dentro do País.

No primeiro cenário, choques favoráveis das vendas externas nos dois grandes grupos de produtos do agronegócio não comprometem a oferta de todas as atividades do sistema produtivo brasileiro, especialmente aquela destinada para os diversos mercados internacionais. A suposição subjacente nesse cenário denota que o sistema produtivo brasileiro é simultaneamente capaz de absorver a pressão de alta da demanda interna e preservar a sua participação em outros mercados externos. Já no segundo cenário, admite-se que as expansões na demanda externa do agronegócio, ao estimular as demandas e os preços nos diversos mercados domésticos, implicam em realocações da produção doméstica em termos intra e intersetorial. Assim, uma vez que as atividades do agronegócio buscam maximizar suas receitas, as ofertas dos produtos finais seriam destinadas para um mercado externo de maior preço em detrimento ao mercado nacional e aos demais

13. Os choques nos modelos de Equilíbrio Geral Computável (EGC) do tipo do modelo ORANI-G, no qual o modelo LATES-BR está baseado, são implementados como variações percentuais em relação à economia que está calibrada. No caso do presente modelo, a economia brasileira está representada pelo ano de 2011. mercados externos. Por outro lado, com a elevação dos preços no mercado interno, o deslocamento da oferta de diversos insumos, em favor ao mercado doméstico, também ocorreria neste segundo cenário. O principal aspecto da distinção entre esses dois cenários reside na tentativa de apontar que os benefícios gerados pelas exportações do agronegócio brasileiro poderiam ser reduzidos ou amortecidos diante de uma eventual realocação da produção dentro do País, estimulado indiretamente pelos choques favoráveis de exportação no sistema produtivo brasileiro. Esse é um ponto que parece despercebido pelo PNE, talvez em virtude da contração das atividades setoriais no País, especialmente nos últimos anos.

Portanto, essa estratégia permite explorar algumas das potencialidades analíticas permitidas pela desagregação do vetor de exportações no modelo. Destarte, essa estratégia permite comparar os prováveis efeitos projetados entre os países e a União Europeia, bem como entre os dois cenários (1 e 2). Os exercícios de simulação podem ser tomados como proxy para o aumento nas relações de comércio entre Brasil e os parceiros externos. Como mencionado, nem todos os países reconhecidos no modelo são os principais parceiros comerciais, porém, o MDIC e o Mapa, por meio do Plano Nacional de Exportações e Projeções do Agronegócio, respectivamente (BRASIL, 2015b, 2015a), os tratam como mercados potenciais. Alguns deles estão localizados no continente americano e, desse modo, os resultados projetados das simulações podem contribuir para o debate de potenciais políticas e acordos bilaterais com o Brasil. As repercussões projetadas e decorrentes dessas análises podem ser observadas tanto sobre os indicadores macroeconômicos quanto os setoriais. Para alcançar tais resultados, operacionalmente é preciso definir o ambiente econômico da simulação, qualificado por um conjunto de hipóteses descritas em um fechamento (classificação das variáveis exógenas para uma simulação). Por essa razão, a definição do fechamento em modelos EGC é um elemento chave para o processo de solução (DIXON e RIMMER, 2002) e exige cuidados, pois 
o ambiente econômico deve ter coerência com o propósito do trabalho.

Diante disso, como as variações exógenas das exportações frequentemente dependem de situações cíclicas e fatores especialmente conjunturais na economia internacional (e.g., mudanças externas de políticas cambiais, renda e expectativas), as simulações procedem em um ambiente econômico denominado de "curto prazo", cujas hipóteses utilizadas seguem o padrão da literatura de equilíbrio geral computável. Nesse tipo de fechamento, o consumo agregado das famílias é exógeno ${ }^{14}$, enquanto o saldo comercial como proporção do Produto Interno Bruto (PIB) é endógeno. Assim, se a expansão das exportações aumentar o PIB no País, a balança comercial (endógena) poderia mover-se em direção a um superavit, mas sem alterar o bem-estar (consumo) das famílias perante a uma provável mudança nos preços relativos nos mercados. Portanto, os volumes de exportação e importação são determinados endogenamente. Além disso, cabe mencionar que no modelo não há uma conexão explícita entre remuneração dos fatores e o consumo das famílias (renda). Essa ligação é resolvida pelo fechamento do modelo, em que consumo das famílias, se endógeno, ajusta-se para equilibrar as variações do PIB pelo lado da renda (remunerações de capital e trabalho) e do dispêndio [ver Horridge (2000)].

Em consonância com a hipótese de país pequeno, os preços dos importados são fixos, o que implica que a demanda brasileira não é capaz de modificar os preços mundiais. A taxa de câmbio nominal é considerada um numerário (exógeno), de forma que elevações dos índices domésticos

14. Em todos os modelos de EGC, a decisão de fechamento pode ter impactos sobre a dimensão dos resultados. No caso do presente trabalho, a decisão de tornar o consumo das famílias exógeno pode impactar a amplitude dos resultados do choque. A adoção desse fechamento não permite, por exemplo, que uma parcela expressiva dos efeitos do aumento da produção agrícola sejam observados. Certamente, os salários pagos pela agricultura, transformados em consumo, poderiam fazer com que os efeitos do aumento das exportações agrícolas sobre o PIB fossem maiores do que os efeitos do aumento das exportações de produtos agroindustriais. de preços representam desvalorizações na taxa real de câmbio. Como o índice de bem-estar é constante (consumo privado), os salários reais devem ser fixos e, portanto, admite-se rigidez no mercado de trabalho. Assim, endogenamente o emprego agregado ajusta-se entre os setores para acomodar a diferença entre os salários nominais e o índice de preço ao consumidor. Ou melhor, mudanças no PIB refletem no emprego agregado da economia. E, uma vez que a balança comercial é endógena, o consumo do governo e a formação bruta de capital (investimentos e variações de estoque) são exógenos. Essas hipóteses refletem que a variação no PIB se manifesta somente perante as mudanças na balança comercial do País, ao invés dos outros componentes de absorção. Esse ponto está condizente com o propósito deste artigo, uma vez que o ambiente econômico das simulações permite tratar apenas dos desdobramentos econômicos refletidos nas relações de comércio internacional, isolando-os dos demais componentes de absorção na economia. Um aspecto relevante desse fechamento é que ajustes negativos no PIB levaria à despoupança da economia, devido à necessidade de ajuste da balança comercial por meio de deficit.

Ademais, bem como o investimento agregado nacional, o estoque de capital setorial é exógeno. Como esse fator de produção é constante, o preço da renda do capital ajusta-se conforme a variação de atividade dos setores, principalmente naqueles intensivos em capital. Consequentemente, o investimento agregado é distribuído entre os setores, conforme a taxa de retorno relativa. Portanto, os investimentos oscilam entre os setores em função das mudanças das taxas de retorno, mas no agregado mantém-se constante.

Por fim, vale ressaltar que as simulações com o modelo LATES-BR foram operacionalizadas no programa GEMPACK ${ }^{15}$ (HARRISON e PEARSON, 2002) e os resultados das simulações foram computados pelo procedimento Gragg 2-4-6 sob o fechamento de curto prazo, conforme descrito acima.

15. Uma versão demonstração do programa está disponível em <http://www.copsmodels.com/gempack.htm>. 


\section{Resultados projetados}

\subsection{Resultados macroeconômicos}

Diante do ambiente econômico especificado para as simulações desse trabalho, o Produto Interno Bruto (PIB) se ajusta conforme as variações marginais da balança comercial, uma vez que os demais componentes de absorção da demanda final são mantidos constantes. A expansão de $10 \%$ das exportações do agronegócio em cada destino estimularia a oferta desses bens e com a expansão do nível de produção, o agronegócio passaria a demandar mais insumos intermediários e fatores primários (capital, trabalho e terra) no seu processo produtivo, o que estimularia direta e indiretamente a demanda dos diversos mercados na economia brasileira, uma vez que as transmissões dos efeitos ocorreriam pelos encadeamentos produtivos existentes. Por consequência, haveria também uma pressão de alta sobre os custos e preços nos mercados domésticos. A expansão geral dos preços da economia tornaria os produtos domésticos menos competitivos e, dada a possibilidade de substituição entre bens domésticos e importados, acabariam por estimular as importações na economia.

Portanto, sob as condições supracitadas e com o intuito de apresentar os efeitos de curto prazo do crescimento de $10 \%$ das exportações das agrícolas e dos produtos agroindustriais em cada um dos mercados de destino, as Tabelas 1 e 2 trazem os resultados sobre os principais indicadores macroeconômicos.

Para o caso das exportações agrícolas, Tabela 1, em ambos os cenários, sem e com realocação da produção dentro do País, essa expansão provocaria efeitos positivos sobre o PIB brasileiro. Entretanto, como no primeiro cenário inexiste a possibilidade de realocação da produção dentro do País, ou seja, as atividades domésticas não deixariam de atender o mercado externo em favor do interno, o efeito sobre o PIB seria maior em cada destino tratado, cujos resultados conjuntamente atingiriam $0,04244 \%$. Por outro lado, a suposição que as atividades exportado- ras redirecionam as suas ofertas de produção no mercado com o preço relativamente maior, por vezes, deixando de atender outros mercados internacionais, implicaria em menor expansão na atividade econômica do País (em um total de $0,00433 \%$ ). Independente das hipóteses subjacentes em cada cenário, esses estímulos da atividade econômica levariam à expansão dos custos no Brasil. Um indicador que representa uma referência geral dos custos e preços internos na economia é o deflator implícito do PIB e, em razão do primeiro cenário preservar a participação das atividades de exportações em outros mercados externos, o mesmo alcançaria variação positiva relativamente maior $(1,61844 \%)$. Em suma, essa observação, associada com a variação positiva da taxa de crescimento do PIB, sinaliza que a expansão das exportações agrícolas promoveria um efeito-atividade na economia brasileira.

As elevações dos custos internos da economia, decorrentes das simulações do segundo cenário (com realocação da produção dentro do País), amenizariam ou afetariam negativamente a taxa de crescimento das exportações. Na prática, haveria, portanto, efeitos negativos da realocação da produção dentro do País e da perda de competitividade das atividades exportadoras sobre os resultados das exportações. Como a projeção do PIB está diretamente relacionada à variação da balança comercial, para alguns destinos haveria um deficit na margem do saldo comercial. O crescimento das exportações agrícolas em alguns destinos internacionais geraria uma despoupança da economia, devido à necessidade de ajuste do deficit marginal na balança comercial, repercutindo negativamente sobre o PIB. Esse é o caso das vendas externas no Cenário 2 para a África do Sul, Arábia Saudita, Colômbia, Índia e Peru. Nesses destinos, apesar do choque favorável nas exportações agrícolas, a realocação da produção dentro do País e a perda de competitividade influenciariam negativamente às exportações. Além disso, dada a possibilidade de substituição entre bens domésticos e importados, as alterações positivas dos preços internos estimulariam as importações na economia e, diante das projeções nas 
exportações brasileiras, as variações positivas das importações levariam a um deficit marginal na balança comercial. Assim, pelas razões expostas, esses resultados sinalizariam que, mesmo diante de uma provável expansão das exportações agrícolas para certos mercados externos, certa restrição na oferta de produção e a elevação dos preços das atividades exportadoras poderiam gerar efeitos contracionistas ao invés de expansionistas na economia brasileira.

Já em um cenário sem realocação da produção dentro do País (Cenário 1), os resultados de curto prazo se mostrariam positivos para a poupança interna, uma vez que o saldo marginal na balança comercial seria positivo. Os efeitos não seriam maiores porque a perda de competitividade da economia brasileira estimularia as importações e amenizaria a expansão das exportações. Destinos das exportações agrícolas como a China, Estados Unidos, Venezuela e Japão estimulariam relativamente mais a atividade econômica no Brasil, pois são mercados externos com grande participação na pauta das exportações agrícolas, responsáveis por $28,4 \%, 21,0 \%, 3,0 \%$ e $6,1 \%$ do total exportado pelo Brasil (ano-base do modelo). Ademais, os resultados projetados reforçariam o papel da China no processo de absorção dos produtos agrícolas brasileiros, que, ao mesmo tempo, promoveria um crescimento de 0,01538\% na economia brasileira. Cabe ressaltar que, embora essas projeções reflitam, em alguma medida, as participações desses mercados nas exportações agrícolas, as simulações realizadas englobam transmissões e efeitos diferenciados nos diversos mercados em virtude das assimetrias na estrutura de custos e demanda de cada atividade agrícola, bem como nas especificações teóricas do modelo, parte delas relacionadas às mudanças nos preços relativos. Em suma, esse conjunto de processos está subjacente em cada simulação, o que tornaria os efeitos econômicos desproporcionais em relação à participação do mercado correspondente na pauta exportadora.

De modo geral, os resultados projetados a partir das expansões das exportações agrícolas

Tabela 1. Efeitos das exportações agrícolas sobre os principais agregados econômicos (var. \%)

\begin{tabular}{|c|c|c|c|c|c|c|c|c|}
\hline \multirow{2}{*}{ Destinos } & \multicolumn{2}{|c|}{ PIB } & \multicolumn{2}{|c|}{ Exportação } & \multicolumn{2}{|c|}{ Importação } & \multicolumn{2}{|c|}{ Deflator do PIB } \\
\hline & Cenário 1 & Cenário 2 & Cenário 1 & Cenário 2 & Cenário 1 & Cenário 2 & Cenário 1 & Cenário 2 \\
\hline África do Sul & 0,00005 & $-0,00002$ & 0,00181 & 0,00057 & 0,00135 & 0,00069 & 0,00255 & 0,00119 \\
\hline Arábia Saudita & 0,00068 & $-0,00003$ & 0,02380 & 0,00659 & 0,01756 & 0,00673 & 0,03473 & 0,01265 \\
\hline Argentina & 0,00025 & 0,00000 & 0,00749 & 0,00174 & 0,00519 & 0,00171 & 0,01106 & 0,00367 \\
\hline Chile & 0,00005 & 0,00001 & 0,00118 & 0,00025 & 0,00073 & 0,00020 & 0,00172 & 0,00051 \\
\hline China & 0,01538 & 0,00231 & 0,38097 & 0,11413 & 0,23887 & 0,08950 & 0,57424 & 0,24703 \\
\hline Colômbia & 0,00016 & $-0,00001$ & 0,00488 & 0,00140 & 0,00336 & 0,00139 & 0,00776 & 0,00358 \\
\hline Coréia do Sul & 0,00051 & 0,00004 & 0,01282 & 0,00223 & 0,00810 & 0,00182 & 0,01945 & 0,00494 \\
\hline Cuba & 0,00010 & 0,00000 & 0,00275 & 0,00059 & 0,00181 & 0,00054 & 0,00427 & 0,00144 \\
\hline Equador & 0,00004 & 0,00001 & 0,00114 & 0,00031 & 0,00072 & 0,00026 & 0,00169 & 0,00066 \\
\hline União Europeia & 0,01202 & 0,00095 & 0,31278 & 0,07574 & 0,20203 & 0,06484 & 0,46782 & 0,16001 \\
\hline Estados Unidos & 0,00293 & 0,00020 & 0,07191 & 0,01271 & 0,04488 & 0,01046 & 0,10768 & 0,02789 \\
\hline Índia & 0,00002 & $-0,00002$ & 0,00080 & 0,00022 & 0,00064 & 0,00035 & 0,00138 & 0,00083 \\
\hline Japão & 0,00165 & 0,00006 & 0,04232 & 0,00742 & 0,02705 & 0,00654 & 0,06451 & 0,01742 \\
\hline México & 0,00013 & 0,00000 & 0,00339 & 0,00058 & 0,00216 & 0,00053 & 0,00514 & 0,00137 \\
\hline Paraguai & 0,00013 & 0,00004 & 0,00291 & 0,00113 & 0,00173 & 0,00076 & 0,00396 & 0,00193 \\
\hline Peru & 0,00006 & $-0,00001$ & 0,00189 & 0,00049 & 0,00133 & 0,00053 & 0,00307 & 0,00136 \\
\hline Rússia & 0,00037 & 0,00003 & 0,00894 & 0,00144 & 0,00555 & 0,00109 & 0,01341 & 0,00299 \\
\hline Uruguai & 0,00009 & 0,00004 & 0,00151 & 0,00078 & 0,00075 & 0,00039 & 0,00164 & 0,00091 \\
\hline Venezuela & 0,00139 & 0,00078 & 0,02289 & 0,01229 & 0,01052 & 0,00524 & 0,02309 & 0,01233 \\
\hline Restante do Mundo & 0,00645 & $-0,00005$ & 0,18049 & 0,04821 & 0,11988 & 0,04594 & 0,26928 & 0,10727 \\
\hline Total & 0,04244 & 0,00433 & 1,08668 & 0,28882 & 0,69421 & 0,23952 & 1,61844 & 0,60999 \\
\hline
\end{tabular}

Nota: Cenário 1: sem realocação da produção dentro do País; Cenário 2 com realocação da produção dentro do País.

Fonte: Elaboração própria a partir dos resultados da pesquisa. 
Tabela 2. Impacto das exportações agroindustriais sobre os principais agregados econômicos (var. \%)

\begin{tabular}{|c|c|c|c|c|c|c|c|c|}
\hline \multirow{2}{*}{ Destinos } & \multicolumn{2}{|c|}{ PIB } & \multicolumn{2}{|c|}{ Exportação } & \multicolumn{2}{|c|}{ Importação } & \multicolumn{2}{|c|}{ Deflator do PIB } \\
\hline & Cenário 1 & Cenário 2 & Cenário 1 & Cenário 2 & Cenário 1 & Cenário 2 & Cenário 1 & Cenário 2 \\
\hline África do Sul & 0,001309 & 0,000775 & 0,017660 & 0,009742 & 0,006090 & 0,002879 & 0,012814 & 0,006432 \\
\hline Arábia Saudita & 0,006013 & 0,003846 & 0,074690 & 0,043856 & 0,021851 & 0,010091 & 0,047080 & 0,023663 \\
\hline Argentina & 0,001434 & 0,000863 & 0,023310 & 0,013487 & 0,010471 & 0,005727 & 0,021536 & 0,012345 \\
\hline Chile & 0,001084 & 0,000693 & 0,016811 & 0,010228 & 0,007144 & 0,004022 & 0,014477 & 0,008545 \\
\hline China & 0,006702 & 0,003548 & 0,101906 & 0,051077 & 0,042127 & 0,019325 & 0,087585 & 0,041982 \\
\hline Colômbia & 0,000537 & 0,000192 & 0,010731 & 0,005048 & 0,005833 & 0,003205 & 0,011492 & 0,006402 \\
\hline Coreia do Sul & 0,001200 & 0,000683 & 0,017647 & 0,009350 & 0,006966 & 0,003263 & 0,013502 & 0,006204 \\
\hline Cuba & 0,000752 & 0,000456 & 0,010395 & 0,005727 & 0,003732 & 0,001690 & 0,007182 & 0,003153 \\
\hline Equador & 0,000126 & 0,000075 & 0,001913 & 0,001070 & 0,000792 & 0,000400 & 0,001579 & 0,000814 \\
\hline União Europeia & 0,024717 & 0,015641 & 0,372637 & 0,218555 & 0,152353 & 0,079017 & 0,302210 & 0,158245 \\
\hline Estados Unidos & 0,003836 & 0,002093 & 0,066893 & 0,036289 & 0,032317 & 0,017247 & 0,064760 & 0,035336 \\
\hline Índia & 0,000670 & 0,000354 & 0,009958 & 0,004824 & 0,003995 & 0,001668 & 0,008107 & 0,003403 \\
\hline Japão & 0,005594 & 0,003788 & 0,066378 & 0,041827 & 0,017359 & 0,008639 & 0,035190 & 0,018267 \\
\hline México & 0,000182 & 0,000092 & 0,003164 & 0,001628 & 0,001528 & 0,000789 & 0,003183 & 0,001720 \\
\hline Paraguai & 0,000577 & 0,000240 & 0,012019 & 0,006133 & 0,006733 & 0,003849 & 0,013396 & 0,007896 \\
\hline Peru & 0,000318 & 0,000179 & 0,004842 & 0,002575 & 0,002010 & 0,000973 & 0,004026 & 0,001980 \\
\hline Rússia & 0,008261 & 0,004912 & 0,124330 & 0,068480 & 0,050770 & 0,024697 & 0,109702 & 0,057959 \\
\hline Uruguai & 0,000623 & 0,000273 & 0,012046 & 0,006187 & 0,006379 & 0,003632 & 0,012623 & 0,007352 \\
\hline Venezuela & 0,003903 & 0,002308 & 0,056678 & 0,031765 & 0,022020 & 0,011217 & 0,046017 & 0,024866 \\
\hline Restante do Mundo & 0,045627 & 0,028931 & 0,669006 & 0,396215 & 0,263401 & 0,138874 & 0,559775 & 0,317366 \\
\hline Total & 0,113465 & 0,069942 & 1,673014 & 0,964063 & 0,663871 & 0,341204 & 1,376236 & 0,743930 \\
\hline
\end{tabular}

Nota: Cenário 1: sem realocação da produção dentro do País; Cenário 2 com realocação da produção dentro do País.

Fonte: Elaboração própria a partir dos resultados da pesquisa.

se diferenciam tanto em termos quantitativos quando em termos de direção do resultado, ou seja, direcionamento das variações. Ao impor a realocação da produção dentro do País verifica-se que uma expansão das exportações agrícolas estimularia um crescimento relativamente menor sobre o PIB brasileiro, pois seria necessário ajuste tanto nos insumos intermediários quanto no uso de fatores primários para atender tal expansão das exportações. Dentro desse cenário é também perceptível o destaque dos mercados da China e dos Estados Unidos, com variações positivas no PIB de $0,00231 \%$ e $0,00020 \%$, respectivamente.

Como as atividades exportadoras do setor agrícola são atividades primárias de tal modo que apresentam razoável integração no sistema produtivo brasileiro ${ }^{16}$, as expansões de suas atividades gerariam efeitos positivos menores para a economia brasileira se comparados aos setores

16. Para uma análise do sistema produtivo brasileiro a partir da matriz de insumo-produto de 2011, ver Betarelli Junior, Perobelli e Vale (2015a). tradicionais que incluem as atividades produtoras de bens processados. Por serem atividades como maior integração no sistema produtivo brasileiro, os efeitos econômicos do crescimento de $10 \%$ das exportações de bens agroindustriais (processados) seriam mais intensivos e transmitidos por um número maior de canais. Essa hipótese é ratificada pelos resultados projetados sobre as principais variáveis macroeconômicas, como observados na Tabela 2. Os mecanismos e as principais relações causais subjacentes dos resultados são semelhantes aos analisados para as exportações agrícolas.

Em ambos os cenários, as expansões das exportações agroindustriais estimulariam o crescimento do PIB brasileiro e, em virtude da ausência da hipótese de realocação da produção dentro do País, no cenário 1 a atividade econômica do País cresceria aproximadamente $0,113465 \%$, quase o dobro do resultado do cenário 2. Associadas a essas projeções, as variações positivas do deflator implícito do PIB sinalizariam que essas simulações provocariam também um efeito-atividade na 
economia brasileira (um total de 1,376236\% e $0,743930 \%$, respectivamente). A elevação dos custos e preços internos na economia repercute positivamente para o volume de importações e negativamente para o volume de exportações no cenário 2. Entretanto, apesar dessa perda de competitividade, ainda se observaria um saldo marginal da balança comercial brasileira (acumulo de poupança interna). Diferente das exportações agrícolas, tal observação é válida para as exportações agroindustriais de todos os mercados no cenário 2, que capta tanto os efeitos negativos da realocação da produção dentro do país quanto os da perda de competitividade.

Os maiores desdobramentos econômicos sobre o PIB brasileiro seriam aquelas exportações de bens processados transacionadas para a Rússia $(0,008261 \%)$, China $(0,006702 \%)$, Arábia Saudita $(0,006013 \%)$ e Japão $(0,005594 \%)$. Juntos, esses mercados, de acordo com os dados do Sistema Alice Web do Ministério do Desenvolvimento, Indústria e Comércio Exterior (MDIC) e, portanto, os dados de calibragem do modelo, são responsáveis por $58 \%$ do total exportado de bens agrícolas processados do Brasil (ano 2011). As exportações desse grupo contribuiriam acima da média de todos os mercados considerados. Portanto, em virtude da integração característica no sistema produtivo brasileiro, as expansões de $10 \%$ das vendas externas dos bens processados proveriam efeitos econômicos relativamente maiores nos dois cenários, se comparados com os resultados projetados na Tabela 1. As maiores contribuições sobre as variações positivas sobre o PIB, exportações, importações e preços internos da economia brasileira seriam aquelas exportações agroindustriais destinadas justamente para os mercados tradicionais em suas correspondentes pautas exportadoras.

Portanto, a distinção das hipóteses em cada cenário mostra-se importante, uma vez que permite evidenciar o quanto uma possível restrição na capacidade de oferta dessas atividades exportadoras reduzir-se-ia os efeitos positivos na economia brasileira, cujo ponto se apresenta como latente no Plano Nacional de Exportações (PNE).

\subsection{Resultados setoriais}

Conforme abordado anteriormente, o crescimento das exportações do agronegócio pressionaria a demanda dos insumos intermediários, estimulando a expansão da oferta das atividades domésticas na economia brasileira e esses efeitos seriam relativamente mais intensos e maiores naqueles setores ou fornecedores mais diretamente integrados às atividades do agronegócio. Consequentemente, além das atividades exportadoras do agronegócio, os seus fornecedores passariam a requerer mais insumos intermediários e fatores primários no seu processo produtivo, o que levaria à alta dos preços e dos custos em diversos mercados. Como o capital e a terra são constantes no curto prazo, a expansão das atividades setoriais ocorreria mediante contratações adicionais de trabalho. Contudo, as atividades intensivas em capital exibiriam maiores dificuldades de expansão da produção, uma vez que esse fator primário não varia no curto prazo. Como decorrência disso, ter-se-ia uma alta do preço da renda do capital e relativamente maior ao preço do trabalho, principalmente mais percebidas e sentidas pelas atividades intensivas em capital. Em suma, o resultado seria a pressão de alta dos preços internos e custos das atividades domésticas, em que os setores intensivos de capital apresentariam restrições de expansão da produção, tanto pela elevação dos custos internos da economia como por depender dos fatores primários, capital e terra. Certamente, essa restrição e perda de competitividade implicariam também em perda da sua participação no mercado interno frente aos insumos e bens importados, dada a possibilidade de substituição imperfeita entre bens domésticos e importados na especificação teórica do modelo LATES-BR.

Portanto, com o intuito de observar os efeitos sobre as grandes atividades econômicas brasileiras, a Tabela 3 apresenta os resultados projetados do crescimento de $10 \%$ das exportações agrícolas sobre a agropecuária, indústria extrativa, agroindústria, indústria em geral, comércio e serviços. A análise é feita dividindo os setores mais beneficiados (ganhadores) e os mais prejudicados (perdedores) 
Tabela 3. Efeitos econômicos das exportações agrícolas sobre a produção das grandes atividades econômicas no Brasil (var. \%)

\begin{tabular}{|c|c|c|c|c|c|c|c|c|c|c|c|c|}
\hline \multirow{2}{*}{ Destinos } & \multicolumn{2}{|c|}{ Agropecuária } & \multicolumn{2}{|c|}{ Extrativa } & \multicolumn{2}{|c|}{ Agroindustriais } & \multicolumn{2}{|c|}{ Indústria } & \multicolumn{2}{|c|}{ Comércio } & \multicolumn{2}{|c|}{ Serviços } \\
\hline & Cen. 1 & Cen. 2 & Cen. 1 & Cen. 2 & Cen. 1 & Cen. 2 & Cen. 1 & Cen. 2 & Cen. 1 & Cen. 2 & Cen. 1 & Cen. 2 \\
\hline África do Sul & 0,00140 & 0,00090 & $-0,00005$ & $-0,00014$ & $-0,00062$ & $-0,00068$ & $-0,00006$ & $-0,00009$ & 0,00011 & 0,00001 & $-0,00002$ & $-0,00005$ \\
\hline Arábia Saudita & 0,02534 & 0,01339 & $-0,00058$ & $-0,00134$ & $-0,00500$ & $-0,00411$ & $-0,00277$ & $-0,00207$ & 0,00037 & $-0,00048$ & $-0,00037$ & $-0,00040$ \\
\hline Argentina & 0,00794 & 0,00352 & $-0,00019$ & $-0,00041$ & $-0,00176$ & $-0,00109$ & $-0,00060$ & $-0,00050$ & 0,00026 & $-0,00005$ & $-0,00012$ & $-0,00012$ \\
\hline Chile & 0,00130 & 0,00054 & $-0,00003$ & $-0,00006$ & $-0,00034$ & $-0,00018$ & $-0,00003$ & $-0,00004$ & 0,00006 & 0,00001 & $-0,00002$ & $-0,00002$ \\
\hline China & 0,44114 & 0,27439 & $-0,00881$ & $-0,02550$ & $-0,12343$ & $-0,11872$ & $-0,01226$ & $-0,01438$ & 0,01383 & $-0,00435$ & $-0,00623$ & $-0,00782$ \\
\hline Colômbia & 0,00452 & 0,00291 & $-0,00014$ & $-0,00042$ & $-0,00158$ & $-0,00160$ & $-0,00018$ & $-0,00024$ & 0,00035 & 0,00006 & $-0,00008$ & $-0,00012$ \\
\hline Coreia do Sul & 0,01452 & 0,00521 & $-0,00030$ & $-0,00052$ & $-0,00444$ & $-0,00248$ & $-0,00035$ & $-0,00027$ & 0,00053 & $-0,00005$ & $-0,00020$ & $-0,00015$ \\
\hline Cuba & 0,00287 & 0,00132 & $-0,00007$ & $-0,00016$ & $-0,00100$ & $-0,00075$ & $-0,00008$ & $-0,00008$ & 0,00015 & 0,00001 & $-0,00004$ & $-0,00005$ \\
\hline Equador & 0,00119 & 0,00066 & $-0,00003$ & $-0,00008$ & $-0,00033$ & $-0,00026$ & $-0,00003$ & $-0,00004$ & 0,00008 & 0,00002 & $-0,00002$ & $-0,00002$ \\
\hline União Europeia & 0,34957 & 0,16634 & $-0,00744$ & $-0,01687$ & $-0,09849$ & $-0,06958$ & $-0,01280$ & $-0,01270$ & 0,01237 & $-0,00175$ & $-0,00493$ & $-0,00500$ \\
\hline Estados Unidos & 0,08033 & 0,02760 & $-0,00171$ & $-0,00298$ & $-0,02512$ & $-0,01282$ & $-0,00141$ & $-0,00155$ & 0,00337 & 0,00003 & $-0,00110$ & $-0,00087$ \\
\hline Índia & 0,00052 & 0,00038 & $-0,00004$ & $-0,00011$ & $-0,00007$ & $-0,00014$ & $-0,00008$ & $-0,00012$ & 0,00005 & 0,00000 & $-0,00002$ & $-0,00003$ \\
\hline Japão & 0,04671 & 0,01688 & $-0,00102$ & $-0,00187$ & $-0,01503$ & $-0,00861$ & $-0,00111$ & $-0,00105$ & 0,00192 & $-0,00011$ & $-0,00066$ & $-0,00054$ \\
\hline México & 0,00363 & 0,00117 & $-0,00009$ & $-0,00015$ & $-0,00111$ & $-0,00053$ & $-0,00008$ & $-0,00009$ & 0,00018 & 0,00002 & $-0,00005$ & $-0,00005$ \\
\hline Paraguai & 0,00324 & 0,00242 & $-0,00006$ & $-0,00022$ & $-0,00065$ & $-0,00070$ & $-0,00009$ & $-0,00013$ & 0,00022 & 0,00007 & $-0,00004$ & $-0,00007$ \\
\hline Peru & 0,00173 & 0,00105 & $-0,00005$ & $-0,00016$ & $-0,00066$ & $-0,00065$ & $-0,00008$ & $-0,00010$ & 0,00013 & 0,00001 & $-0,00003$ & $-0,00004$ \\
\hline Rússia & 0,01037 & 0,00338 & $-0,00020$ & $-0,00031$ & $-0,00311$ & $-0,00152$ & $-0,00021$ & $-0,00014$ & 0,00036 & $-0,00003$ & $-0,00014$ & $-0,00009$ \\
\hline Uruguai & 0,00186 & 0,00158 & $-0,00002$ & $-0,00010$ & $-0,00024$ & $-0,00033$ & $-0,00002$ & $-0,00005$ & 0,00013 & 0,00007 & $-0,00001$ & $-0,00003$ \\
\hline Venezuela & 0,03088 & 0,02653 & $-0,00012$ & $-0,00130$ & $-0,00400$ & $-0,00528$ & $-0,00020$ & $-0,00060$ & 0,00182 & 0,00088 & $-0,00019$ & $-0,00038$ \\
\hline Restante do Mundo & 0,18380 & 0,10023 & $-0,00434$ & $-0,01183$ & $-0,06158$ & $-0,05611$ & $-0,00565$ & $-0,00652$ & 0,00942 & 0,00049 & $-0,00263$ & $-0,00368$ \\
\hline Total & 1,21284 & 0,65040 & $-0,02527$ & $-0,06451$ & $-0,34857$ & $-0,28613$ & $-0,03809$ & $-0,04077$ & 0,04570 & $-0,00516$ & $-0,01690$ & $-0,01951$ \\
\hline
\end{tabular}

Nota: Cenário 1: sem realocação da produção dentro do País; Cenário 2 com realocação da produção dentro do País.

Fonte: Elaboração própria a partir dos resultados da pesquisa.

pela expansão das vendas externas dos produtos agrícolas. Como descrito, é importante salientar que o resultado para a variação do nível de atividade está diretamente relacionado ao uso de insumos intermediários por parte dos setores produtivos e devido à substituição entre domésticos e importados. Assim sendo, a avaliação da distribuição de setores ganhadores e perdedores é uma medida de integração setorial e, portanto, pode ser tomado como o efeito multiplicador do exercício de simulação na economia do País.

Os resultados projetados se mostram bastante diferentes entre os dois cenários tratados nesse trabalho. A agropecuária apresenta relativamente o maior crescimento em ambos os cenários; entretanto, no agregado, a ausência da realocação da produção dentro do País impulsiona uma expansão de $1,21284 \%$, praticamente o dobro quando comparado com o resultado do segundo cenário. Portanto, os maiores benefícios dessa simulação se concentrariam em termos intrassetoriais da agropecuária. A expansão de produção provocaria uma pressão na demanda dos mercados dos fatores de produção, especialmente o fator trabalho, cujo mercado apresenta rigidez dos salários reais no curto prazo. Conforme a Tabela 4, para atender ao crescimento de $1,21284 \%$ na sua produção, o setor da agropecuária aumentaria em 3,57382\% a contratação de mão de obra. Em seu valor adicionado, as remunerações oriundas do trabalho representam praticamente $40 \%$, enquanto o valor do capital corresponde a $46 \%$. Semelhante aos resultados macroeconômicos, os choques favoráveis seriam mais observados nas vendas externas destinadas aos mercados como China, Estados Unidos, União Europeia, Venezuela e Japão. Embora esses resultados projetados representem a proeminência dos efeitos diretos perante as simulações realizadas no grupo dos produtos agrícolas, efeitos negativos oriundos da perda de competitividade e competição com os importados também estariam presentes.

Somente no cenário 1 , sem realocação da produção dentro do País, que o setor de 
Tabela 4. Efeitos econômicos das exportações agrícolas sobre o emprego das grandes atividades econômicas no Brasil (var. \%)

\begin{tabular}{|c|c|c|c|c|c|c|c|c|c|c|c|c|}
\hline \multirow{2}{*}{ Destinos } & \multicolumn{2}{|c|}{ Agropecuária } & \multicolumn{2}{|c|}{ Extrativa } & \multicolumn{2}{|c|}{ Agroindustriais } & \multicolumn{2}{|c|}{ Indústria } & \multicolumn{2}{|c|}{ Comércio } & \multicolumn{2}{|c|}{ Serviços } \\
\hline & Cen. 1 & Cen. 2 & Cen. 1 & Cen. 2 & Cen. 1 & Cen. 2 & Cen. 1 & Cen. 2 & Cen. 1 & Cen. 2 & Cen. 1 & Cen. 2 \\
\hline África do Sul & 0,00419 & 0,00259 & $-0,00029$ & $-0,00090$ & $-0,00093$ & $-0,00103$ & $-0,00019$ & $-0,00021$ & 0,00018 & 0,00000 & $-0,00004$ & $-0,00008$ \\
\hline Arábia Saudita & 0,07574 & 0,03795 & $-0,00362$ & $-0,00882$ & $-0,00750$ & $-0,00635$ & $-0,00598$ & $-0,00435$ & 0,00042 & $-0,00106$ & $-0,00062$ & $-0,00062$ \\
\hline Argentina & 0,02339 & 0,00976 & $-0,00120$ & $-0,00268$ & $-0,00267$ & $-0,00171$ & $-0,00140$ & $-0,00105$ & 0,00041 & $-0,00014$ & $-0,00019$ & $-0,00018$ \\
\hline Chile & 0,00372 & 0,00139 & $-0,00018$ & $-0,00038$ & $-0,00051$ & $-0,00027$ & $-0,00011$ & $-0,00010$ & 0,00011 & 0,00001 & $-0,00003$ & $-0,00003$ \\
\hline China & 1,31007 & 0,78172 & $-0,05586$ & $-0,16783$ & $-0,17832$ & $-0,17554$ & $-0,03951$ & $-0,03776$ & 0,02330 & $-0,00980$ & $-0,01063$ & $-0,01210$ \\
\hline Colômbia & 0,01319 & 0,00801 & $-0,00085$ & $-0,00272$ & $-0,00236$ & $-0,00245$ & $-0,00054$ & $-0,00059$ & 0,00059 & 0,00006 & $-0,00013$ & $-0,00018$ \\
\hline Coreia do Sul & 0,04317 & 0,01469 & $-0,00192$ & $-0,00342$ & $-0,00647$ & $-0,00369$ & $-0,00123$ & $-0,00073$ & 0,00091 & $-0,00013$ & $-0,00033$ & $-0,00023$ \\
\hline Cuba & 0,00847 & 0,00369 & $-0,00043$ & $-0,00105$ & $-0,00147$ & $-0,00112$ & $-0,00027$ & $-0,00021$ & 0,00026 & 0,00000 & $-0,00007$ & $-0,00007$ \\
\hline Equador & 0,00335 & 0,00170 & $-0,00017$ & $-0,00050$ & $-0,00050$ & $-0,00041$ & $-0,00011$ & $-0,00010$ & 0,00013 & 0,00002 & $-0,00003$ & $-0,00003$ \\
\hline União Europeia & 1,03893 & 0,47215 & $-0,04721$ & $-0,11096$ & $-0,14552$ & $-0,10575$ & $-0,03746$ & $-0,03056$ & 0,02092 & $-0,00466$ & $-0,00775$ & $-0,00742$ \\
\hline Estados Unidos & 0,23814 & 0,07758 & $-0,01089$ & $-0,01962$ & $-0,03720$ & $-0,01943$ & $-0,00594$ & $-0,00409$ & 0,00592 & $-0,00015$ & $-0,00159$ & $-0,00124$ \\
\hline Índia & 0,00162 & 0,00118 & $-0,00022$ & $-0,00069$ & $-0,00013$ & $-0,00024$ & $-0,00017$ & $-0,00024$ & 0,00009 & $-0,00002$ & $-0,00003$ & $-0,00005$ \\
\hline Japão & 0,13891 & 0,04777 & $-0,00650$ & $-0,01230$ & $-0,02209$ & $-0,01289$ & $-0,00400$ & $-0,00273$ & 0,00330 & $-0,00035$ & $-0,00102$ & $-0,00080$ \\
\hline México & 0,01080 & 0,00333 & $-0,00055$ & $-0,00101$ & $-0,00166$ & $-0,00083$ & $-0,00030$ & $-0,00023$ & 0,00031 & 0,00002 & $-0,00008$ & $-0,00007$ \\
\hline Paraguai & 0,00836 & 0,00575 & $-0,00035$ & $-0,00146$ & $-0,00097$ & $-0,00107$ & $-0,00025$ & $-0,00030$ & 0,00037 & 0,00011 & $-0,00007$ & $-0,00010$ \\
\hline Peru & 0,00514 & 0,00297 & $-0,00034$ & $-0,00103$ & $-0,00097$ & $-0,00097$ & $-0,00022$ & $-0,00024$ & 0,00021 & 0,00000 & $-0,00005$ & $-0,00007$ \\
\hline Rússia & 0,03078 & 0,00949 & $-0,00130$ & $-0,00203$ & $-0,00454$ & $-0,00226$ & $-0,00081$ & $-0,00041$ & 0,00061 & $-0,00008$ & $-0,00023$ & $-0,00014$ \\
\hline Uruguai & 0,00436 & 0,00350 & $-0,00009$ & $-0,00066$ & $-0,00034$ & $-0,00048$ & $-0,00008$ & $-0,00013$ & 0,00023 & 0,00010 & $-0,00002$ & $-0,00004$ \\
\hline Venezuela & 0,07100 & 0,05719 & $-0,00070$ & $-0,00854$ & $-0,00563$ & $-0,00740$ & $-0,00090$ & $-0,00148$ & 0,00313 & 0,00140 & $-0,00029$ & $-0,00056$ \\
\hline Restante do Mundo & 0,54050 & 0,27934 & $-0,02731$ & $-0,07775$ & $-0,09015$ & $-0,08365$ & $-0,01806$ & $-0,01667$ & 0,01586 & $-0,00039$ & $-0,00439$ & $-0,00560$ \\
\hline Total & 3,57382 & 1,82174 & $-0,15996$ & $-0,42431$ & $-0,50991$ & $-0,42753$ & $-0,11750$ & $-0,10218$ & 0,07724 & $-0,01507$ & $-0,02759$ & $-0,02958$ \\
\hline
\end{tabular}

Nota: Cenário 1: sem realocação da produção dentro do País; Cenário 2 com realocação da produção dentro do País.

Fonte: Elaboração própria a partir dos resultados da pesquisa.

comércio seria também a outra grande atividade beneficiada pela expansão das exportações agrícolas (ao todo, atingiria 0,04570\%). As demais grandes atividades teriam certa retração em suas produções, quando avaliadas no agregado, tendo como possíveis justificativas a perda de competitividade, concorrência com os produtos importados no mercado interno, ou por serem caracteristicamente intensivas em capital. Não obstante, se analisados os resultados em termos intrassetoriais de cada grande atividade, os sinais dos efeitos seriam variados, como na Indústria, Comércio e Serviços. Uma vez que há rigidez do salário real no mercado de trabalho, a diminuição do nível de atividade levaria esses grandes setores a requisitar menos trabalho no seu processo produtivo, aumentando a oferta deste fator primário para ser absorvida nas grandes atividades que exibiram expansões de produção.

Já os efeitos positivos do crescimento das exportações de bens agrícolas processados apre- sentam espraiamentos sobre o nível de atividade e emprego nos grandes setores da economia brasileira. Como se trata de um setor mais integrado no sistema produtivo brasileiro, as expansões das vendas externas desses produtos em vários mercados internacionais provocariam estímulos no setor da Agropecuária, Agroindustriais, Comércio e Serviços, independentemente se atribuída à suposição da realocação da produção dentro do País. Como nas projeções já analisadas, a realocação da produção dentro do País geraria desdobramentos positivos relativamente menores por permitir o redirecionamento da oferta das atividades exportadoras, por vezes, comprimindo as participações correspondentes em certos mercados internacionais, e por considerar os efeitos adversos da perda de competitividade tanto no mercado interno quanto no externo. No segundo cenário, apenas esse último efeito negativo estaria incluído nos resultados de curto prazo. De modo geral, os destinos mais promissores em termos de estímulos às grandes 
Tabela 5. Efeitos econômicos das exportações agroindustriais sobre a produção das grandes atividades econômicas no Brasil (var. \%)

\begin{tabular}{|c|c|c|c|c|c|c|c|c|c|c|c|c|}
\hline \multirow{2}{*}{ Destinos } & \multicolumn{2}{|c|}{ Agropecuária } & \multicolumn{2}{|c|}{ Extrativa } & \multicolumn{2}{|c|}{ Agroindustriais } & \multicolumn{2}{|c|}{ Indústria } & \multicolumn{2}{|c|}{ Comércio } & \multicolumn{2}{|c|}{ Serviços } \\
\hline & Cen. 1 & Cen. 2 & Cen. 1 & Cen. 2 & Cen. 1 & Cen. 2 & Cen. 1 & Cen. 2 & Cen. 1 & Cen. 2 & Cen. 1 & Cen. 2 \\
\hline África do Sul & 0,00956 & 0,00613 & 0,00005 & $-0,00068$ & 0,02015 & 0,01555 & $-0,00059$ & $-0,00073$ & 0,00271 & 0,00183 & 0,00023 & 0,00007 \\
\hline Arábia Saudita & 0,04718 & 0,03341 & 0,00059 & $-0,00227$ & 0,09201 & 0,07123 & $-0,00239$ & $-0,00280$ & 0,01156 & 0,00797 & 0,00114 & 0,00048 \\
\hline Argentina & 0,00781 & 0,00438 & $-0,00010$ & $-0,00140$ & 0,01999 & 0,01871 & $-0,00058$ & $-0,00108$ & 0,00422 & 0,00338 & 0,00024 & 0,00001 \\
\hline Chile & 0,00690 & 0,00490 & $-0,00005$ & $-0,00098$ & 0,01547 & 0,01450 & $-0,00033$ & $-0,00070$ & 0,00268 & 0,00209 & 0,00020 & 0,00003 \\
\hline China & 0,04492 & 0,02503 & $-0,00046$ & $-0,00465$ & 0,11148 & 0,08449 & $-0,00612$ & $-0,00631$ & 0,01230 & 0,00739 & 0,00137 & 0,00037 \\
\hline Colômbia & 0,00302 & 0,00116 & $-0,00016$ & $-0,00078$ & 0,00924 & 0,00713 & $-0,00072$ & $-0,00085$ & 0,00123 & 0,00072 & 0,00004 & $-0,00010$ \\
\hline Coreia do Sul & 0,00648 & 0,00308 & 0,00003 & $-0,00066$ & 0,01813 & 0,01447 & $-0,00027$ & $-0,00047$ & 0,00251 & 0,00167 & 0,00030 & 0,00014 \\
\hline Cuba & 0,00394 & 0,00190 & 0,00007 & $-0,00031$ & 0,01094 & 0,00894 & $-0,00005$ & $-0,00018$ & 0,00162 & 0,00114 & 0,00020 & 0,00011 \\
\hline Equador & 0,00066 & 0,00035 & 0,00000 & $-0,00009$ & 0,00180 & 0,00156 & $-0,00003$ & $-0,00006$ & 0,00030 & 0,00022 & 0,00003 & 0,00001 \\
\hline União Europeia & 0,13874 & 0,08032 & $-0,00031$ & $-0,01729$ & 0,36815 & 0,32974 & $-0,00800$ & $-0,01327$ & 0,05167 & 0,03805 & 0,00654 & 0,00322 \\
\hline Estados Unidos & 0,02099 & 0,01086 & $-0,00062$ & $-0,00414$ & 0,05756 & 0,05088 & $-0,00265$ & $-0,00368$ & 0,00963 & 0,00700 & 0,00081 & 0,00013 \\
\hline Índia & 0,00396 & 0,00179 & $-0,00001$ & $-0,00036$ & 0,01113 & 0,00830 & $-0,00058$ & $-0,00055$ & 0,00119 & 0,00071 & 0,00017 & 0,00007 \\
\hline Japão & 0,04024 & 0,02861 & 0,00093 & $-0,00158$ & 0,07838 & 0,06344 & 0,00057 & $-0,00046$ & 0,01180 & 0,00864 & 0,00124 & 0,00067 \\
\hline México & 0,00100 & 0,00044 & $-0,00003$ & $-0,00020$ & 0,00278 & 0,00235 & $-0,00019$ & $-0,00022$ & 0,00050 & 0,00037 & 0,00003 & 0,00000 \\
\hline Paraguai & 0,00243 & 0,00071 & $-0,00020$ & $-0,00096$ & 0,00853 & 0,00769 & $-0,00043$ & $-0,00074$ & 0,00177 & 0,00126 & 0,00007 & $-0,00008$ \\
\hline Peru & 0,00184 & 0,00096 & $-0,00001$ & $-0,00022$ & 0,00488 & 0,00398 & $-0,00017$ & $-0,00022$ & 0,00068 & 0,00047 & 0,00007 & 0,00002 \\
\hline Rússia & 0,06588 & 0,04713 & $-0,00076$ & $-0,00660$ & 0,13986 & 0,11441 & $-0,00926$ & $-0,00955$ & 0,01471 & 0,00980 & 0,00132 & 0,00014 \\
\hline Uruguai & 0,00330 & 0,00142 & $-0,00015$ & $-0,00089$ & 0,00973 & 0,00827 & $-0,00056$ & $-0,00080$ & 0,00163 & 0,00112 & 0,00006 & $-0,00008$ \\
\hline Venezuela & 0,02911 & 0,02002 & $-0,00009$ & $-0,00277$ & 0,06141 & 0,04946 & $-0,00269$ & $-0,00319$ & 0,00787 & 0,00539 & 0,00065 & 0,00008 \\
\hline Restante do Mundo & 0,34170 & 0,24829 & $-0,00215$ & $-0,03517$ & 0,75463 & 0,66299 & $-0,04308$ & $-0,05184$ & 0,08533 & 0,06026 & 0,00790 & 0,00156 \\
\hline Total & 0,77966 & 0,52088 & $-0,00340$ & $-0,08198$ & 1,79623 & 1,53809 & $-0,07811$ & $-0,09770$ & 0,22590 & 0,15945 & 0,02261 & 0,00685 \\
\hline
\end{tabular}

Nota: Cenário 1: sem realocação da produção dentro do País; Cenário 2 com realocação da produção dentro do País.

Fonte: Elaboração própria a partir dos resultados da pesquisa.

atividades econômicas seriam a União Europeia, Rússia, China, Arábia Saudita e China, pois são mercados em que as exportações dos produtos agroindustriais promoveriam não somente fortes efeitos diretos (e.g., efeitos positivos intrassetoriais) mas também efeitos sistêmicos de ordem posteriores (e.g., efeitos intersetoriais positivos). A Indústria Extrativa é caracteristicamente composta por atividades intensivas em capital ${ }^{17}$, o que restringiu, em grande medida, o crescimento da produção no curto prazo diante dos choques favoráveis das exportações na economia brasileira.

O comportamento das atividades dos grandes setores seria também observado nas variações de contratações de mão de obra (Tabela 6). As demandas por trabalho elevariam, sobre-

17. No núcleo de dados do modelo, as participações do Capital no Valor Adicionado do setor de Carvão e Minerais Não Metálicas, Petróleo e Gás, Minério de Ferro e Minerais Não ferrosos foram, respectivamente, $46 \%, 50 \%, 86 \%, 89 \%$ e $54 \%$. tudo, no próprio setor Agroindustrial e nos setores da Agropecuária, Comércio e Serviços, cujas projeções denotam semelhantemente a mesma importância relativa dos mercados internacionais como fonte favorável de crescimento do mercado interno brasileiro. Portanto, no caso desse exercício, há variações positivas no emprego num conjunto maior de setores. A concorrência por mão de obra levaria também a variações negativas no setor extrativo e industrial para a grande maioria dos exercícios implementados. Em geral, os benefícios indiretos em termos intersetoriais reforçariam um papel de destaque dos produtos agroindustriais dentro das estratégias delineadas pela política comercial brasileira, particularmente no Plano Nacional de Exportações (PNE). Conforme evidencias provenientes das projeções setoriais, os produtos agroindustriais relevam efeitos mais intensivos e um número maior de canais de transmissão em um sistema em que os efeitos competitivos e complementares agem simultaneamente. 
Tabela 6. Efeitos econômicos das exportações agroindustriais sobre o emprego das grandes atividades econômicas no Brasil (var. \%)

\begin{tabular}{|c|c|c|c|c|c|c|c|c|c|c|c|c|}
\hline \multirow{2}{*}{ Destinos } & \multicolumn{2}{|c|}{ Agropecuária } & \multicolumn{2}{|c|}{ Extrativa } & \multicolumn{2}{|c|}{ Agroindustriais } & \multicolumn{2}{|c|}{ Indústria } & \multicolumn{2}{|c|}{ Comércio } & \multicolumn{2}{|c|}{ Serviços } \\
\hline & Cen. 1 & Cen. 2 & Cen. 1 & Cen. 2 & Cen. 1 & Cen. 2 & Cen. 1 & Cen. 2 & Cen. 1 & Cen. 2 & Cen. 1 & Cen. 2 \\
\hline África do Sul & 0,02315 & 0,01410 & 0,00050 & $-0,00434$ & 0,03129 & 0,02378 & $-0,00124$ & $-0,00145$ & 0,00508 & 0,00343 & 0,00028 & 0,00006 \\
\hline Arábia Saudita & 0,11064 & 0,07482 & 0,00453 & $-0,01457$ & 0,13839 & 0,10507 & $-0,00491$ & $-0,00557$ & 0,02166 & 0,01492 & 0,00146 & 0,00058 \\
\hline Argentina & 0,01975 & 0,01010 & $-0,00052$ & $-0,00913$ & 0,02965 & 0,02714 & $-0,00146$ & $-0,00226$ & 0,00790 & 0,00633 & 0,00028 & $-0,00004$ \\
\hline Chile & 0,01610 & 0,01045 & $-0,00015$ & $-0,00636$ & 0,02201 & 0,02028 & $-0,00089$ & $-0,00150$ & 0,00500 & 0,00390 & 0,00025 & 0,00002 \\
\hline China & 0,12172 & 0,06550 & $-0,00170$ & $-0,02980$ & 0,19560 & 0,14682 & $-0,01126$ & $-0,01148$ & 0,02306 & 0,01387 & 0,00170 & 0,00037 \\
\hline Colômbia & 0,00871 & 0,00338 & $-0,00089$ & $-0,00503$ & 0,01763 & 0,01371 & $-0,00131$ & $-0,00154$ & 0,00232 & 0,00136 & 0,00005 & $-0,00013$ \\
\hline Coreia do Sul & 0,01724 & 0,00772 & 0,00037 & $-0,00420$ & 0,02788 & 0,02197 & $-0,00080$ & $-0,00104$ & 0,00468 & 0,00311 & 0,00038 & 0,00016 \\
\hline Cuba & 0,01042 & 0,00466 & 0,00056 & $-0,00199$ & 0,01542 & 0,01246 & $-0,00031$ & $-0,00046$ & 0,00302 & 0,00212 & 0,00026 & 0,00013 \\
\hline Equador & 0,00173 & 0,00082 & 0,00002 & $-0,00058$ & 0,00261 & 0,00223 & $-0,00009$ & $-0,00013$ & 0,00055 & 0,00041 & 0,00004 & 0,00002 \\
\hline União Europeia & 0,36265 & 0,19518 & 0,00225 & $-0,11075$ & 0,56835 & 0,49902 & $-0,02021$ & $-0,02802$ & 0,09632 & 0,07099 & 0,00832 & 0,00386 \\
\hline Estados Unidos & 0,05694 & 0,02769 & $-0,00326$ & $-0,02669$ & 0,09693 & 0,08289 & $-0,00558$ & $-0,00722$ & 0,01802 & 0,01312 & 0,00100 & 0,00007 \\
\hline Índia & 0,01157 & 0,00524 & 0,00009 & $-0,00228$ & 0,01887 & 0,01387 & $-0,00107$ & $-0,00100$ & 0,00223 & 0,00133 & 0,00021 & 0,00009 \\
\hline Japão & 0,08932 & 0,06036 & 0,00650 & $-0,01019$ & 0,10381 & 0,08319 & $-0,00035$ & $-0,00184$ & 0,02204 & 0,01612 & 0,00162 & 0,00085 \\
\hline México & 0,00286 & 0,00125 & $-0,00016$ & $-0,00129$ & 0,00479 & 0,00393 & $-0,00036$ & $-0,00042$ & 0,00093 & 0,00069 & 0,00004 & $-0,00001$ \\
\hline Paraguai & 0,00674 & 0,00190 & $-0,00114$ & $-0,00625$ & 0,01551 & 0,01367 & $-0,00095$ & $-0,00145$ & 0,00331 & 0,00236 & 0,00007 & $-0,00013$ \\
\hline Peru & 0,00497 & 0,00244 & 0,00002 & $-0,00140$ & 0,00767 & 0,00613 & $-0,00037$ & $-0,00043$ & 0,00128 & 0,00088 & 0,00009 & 0,00003 \\
\hline Rússia & 0,16835 & 0,11371 & $-0,00330$ & $-0,04232$ & 0,24095 & 0,19091 & $-0,01643$ & $-0,01725$ & 0,02765 & 0,01844 & 0,00162 & 0,00002 \\
\hline Uruguai & 0,00887 & 0,00359 & $-0,00084$ & $-0,00574$ & 0,01714 & 0,01442 & $-0,00112$ & $-0,00152$ & 0,00306 & 0,00210 & 0,00008 & $-0,00012$ \\
\hline Venezuela & 0,07086 & 0,04582 & 0,00006 & $-0,01783$ & 0,09802 & 0,07722 & $-0,00517$ & $-0,00604$ & 0,01476 & 0,01011 & 0,00082 & 0,00005 \\
\hline Restante do Mundo & 0,88215 & 0,61719 & $-0,00566$ & $-0,22524$ & 1,27427 & 1,10922 & $-0,07826$ & $-0,09319$ & 0,16032 & 0,11349 & 0,00979 & 0,00117 \\
\hline Total & 1,99472 & 1,26594 & $-0,00270$ & $-0,52595$ & 2,92679 & 2,46792 & $-0,15211$ & $-0,18378$ & 0,42321 & 0,29908 & 0,02834 & 0,00704 \\
\hline
\end{tabular}

Nota: Cenário 1: sem realocação da produção dentro do País; Cenário 2 com realocação da produção dentro do País.

Fonte: Elaboração própria a partir dos resultados da pesquisa.

\section{Considerações finais}

Este trabalho trouxe novas evidências em relação aos impactos do comércio internacional, especificamente, as exportações de bens do agronegócio sobre a economia brasileira. A estratégia adotada foi chamar atenção para novos mercados potenciais das exportações agrícolas e agroindustriais brasileiras e então fornecer novos resultados para estes mercados, bem como novas evidências para os mercados tradicionais como Estados Unidos e União Europeia. A análise foi feita para commodities agrícolas e para produtos agroindustriais (bens processados), levando em consideração dois cenários, um sem realocação da produção dentro do País e, portanto, sem restrições de oferta, e um com realocação da produção dentro do País - com restrição de oferta. As diferenças entre os resultados foram bastantes interessantes, pois mostraram o efeito multipli- cador dos bens processados destinados à exportação e indiretamente o efeito multiplicador das commodities agrícolas.

O tamanho dos impactos dos potenciais mercados, principalmente países da América do Sul, quando comparados com os mercados tradicionais, no caso os Estados Unidos, é bem menor. Entretanto, conforme abordado ao longo do trabalho, a questão mais importante não é o tamanho do impacto, mas sim o movimento em termos macroeconômicos e os resultados de comércio, ou seja, o potencial de explorar novos mercados como alternativa de aumento da participação brasileira no comércio internacional. Vale ressaltar que o intuito desse trabalho não foi analisar os impactos de uma política comercial brasileira. Pelo contrário, o exercício de simulação imposto, ou seja, variação na quantidade exportada de forma homogênea para todas as regiões analisadas, buscou dar respostas consistentes, com base 
em efeitos sistêmicos, de possíveis alternativas de incentivos a serem adotadas pelos formuladores de política econômica e comercial no País.

Dentro dessa perspectiva, o resultado de impacto sobre a produção setorial, que, no caso do presente trabalho, pode ser entendido como os efeitos multiplicadores do choque, mostram que as alternativas de crescimento baseadas na variação das exportações agrícolas processadas e não processadas têm efeitos multiplicadores, ou de outra forma, efeitos spillovers diferenciados. No caso das commodities agrícolas verificou-se um impacto positivo na produção somente do próprio setor agrícola. Já no caso dos bens processados, foi possível verificar efeitos positivos na produção dos demais setores da economia. Assim, de forma indireta, as exportações de bens processados trazem benefícios para um conjunto maior de setores. Explorar tais resultados podem fazer com que o Brasil não somente amplie sua participação no mercado mundial de comércio, mas também cause efeitos multiplicadores em sua economia.

Portanto, estudos que visam avaliar questões como inserção do País no comércio internacional, por meio de avaliações de produtividade, disponibilidade de capital, mão de obra, entre outros, devem levar em conta toda a cadeia produtiva. Em outras palavras, é necessária uma análise sistêmica da questão antes de qualquer tomada de decisão.

Por fim, dado o debate na literatura sobre o papel do Brasil no processo de integração da América Latina, que passa, em parte, pelos fluxos comerciais, e os resultados de curto prazo aqui encontrados, fica evidente a necessidade de se considerar as potencialidades presentes nos países vizinhos (i.e., nos mercados latino-americanos), sendo oportuno avaliar o papel proativo do Brasil no processo de fortalecimento destas relações econômicas na América Latina. Este papel se torna ainda mais importante no contexto em que se encontra o setor em nível mundial, ou seja, com alto grau de proteção, principalmente nos mercados dos Estados Unidos e União Europeia, e no contexto de acordos bilaterais de comércio.

\section{Referências}

ARMINGTON, P. S. A Theory of Demand for Products Distinguished by Place of Production. International Monetary Fund Staff Papers, v. 16, n. 1, p. 159-178, 1969.

ARROW, K. J. e DEBREU, G. Existence of an Equilibrium for a Competitive Economy. Journal of the Econometric Society, v. 22, n. 3, p. 265-290, 1954.

BARROS, G. S. de C. e ADAMI, A. C de O. Exportações do agronegócio batem novo recorde em 2012, mesmo com queda de preços. Centro de Estudos Avançados em Economia Aplicada - ESALq/USP, 2012.

BARROS, G. S. de C., ADAMI, A. C de O. e ZANDONÁ, N. F. Embarques dos produtos do agronegócio recuam em 2014. Centro de Estudos Avançados em Economia Aplicada - ESALq/USP, 2014.

BARROS, G. S. de C., ADAMI, A. C de O. e ZANDONÁ, N. F. Faturamento e volume exportado do agronegócio brasileiro são recordes em 2013. Centro de Estudos Avançados em Economia Aplicada - ESALq/USP, 2013.

BETARELLI JUNIOR, A. A., PEROBELLI, F. S. e VALE, V. A. Estimação da Matriz de Insumo-Produto de 2011 e Análise do Sistema Produtivo Brasileiro. Programa de Pós-graduação em Economia, Universidade Federal de Juiz de Fora, Juiz de Fora, 2015a. (Texto para discussão 001/2015)

BETARELLI JUNIOR, A. A., PEROBELLI, F. S. e VALE, V. A. Um Modelo Nacional de Equilíbrio Geral Computável Dinâmico-Recursivo (EGC-RD) para o Brasil no ano de 2011 (BIM-RD). Laboratório de Análises Territoriais e Setoriais (LATES), Programa de Pós-Graduação em Economia, Universidade Federal de Juiz de Fora, Juiz de Fora, 2015b. (Texto para discussão 01-2015)

BRASIL. Ministério do Desenvolvimento, Indústria e Comércio Exterior (MDIC). Plano Brasil Maior. Brasília: Ministério do Desenvolvimento, Indústria e Comércio Exterior, 2011.

- Ministério da Agricultura, Pecuária e Abastecimento (MAPA). Projeções do Agronegócio: Brasil 2014/2015 a 2024/2015. Brasília: Ministério da Agricultura, Pecuária e Abastecimento, 2015a.

. Ministério do Desenvolvimento, Indústria e Comércio Exterior (MDIC). Plano Nacional de Exportações 2015-2018. Brasília: Ministério do desenvolvimento, Indústria e Comércio Exterior, 2015b.

CARDOSO, D. F. e TEIXEIRA, E. C. A. Contribuição da Política Agrícola para o Desenvolvimento do Agronegócio nas Macrorregiões Brasileiras. Revista de Economia e Agronegócio, v. 11, p. 39-72, 2013. 
CYPRIANO, L. A. e TEIXEIRA, E. C. Impactos da Alca e do Mercoeuro no agronegócio do Mercosul. Revista de Economia e Sociologia Rural, v. 41, n. 2, p. 217-239, 2003.

DIXON, P. B. et al. ORANI: A Multisectoral Model of the Australian Economy. Amsterdam: North-Holland Pub. Co, 1982.

DIXON, P. B. e RIMMER, M. Dynamic General Equilibrium Modelling for Forecasting and Policy: a practical guide and documentation of MONASH. Amsterdan: Elsevier, 2002.

FERREIRA FILHO, J. B. S. Ajuste estrutural e agricultura na década de 80: uma abordagem de equilíbrio geral. Pesquisa e Planejamento Econômico, v. 27, n. 2, p. 397-432, 1997.

FERREIRA FILHO, J. B. S. Trade Liberalization, the Mercosur Integration process and the agricultureindustry transfers: a general equilibrium analysis. Revista Brasileira de Economia, v. 53, n. 4, p. 499-522, 1999.

FIGUEIREDO, A. M. et al. Impactos dos subsídios agrícolas nos Estados Unidos na expansão do agronegócio brasileiro. Revista Estudos Econômicos, v. 40, n. 2, p. 445-467, 2010.

GUILHOTO, J. J. M. Um modelo computável de equilíbrio geral para planejamento e análise de políticas agrícolas (PAPA) na economia brasileira. 1995. 272f. Tese (Livre Docência). Escola Superior de Agricultura Luiz de Queiroz - Universidade de São Paulo, Piracicaba, 1995.

. e SESSO FILHO, U. A. Estimação da matriz insumo-produto utilizando dados preliminares das contas nacionais: aplicação e análise de indicadores econômicos para o Brasil em 2005. Economia $\mathcal{E}$ Tecnologia, v. 23, p. 53-62, 2010.

. e SESSO FILHO, U. A. Estimação da matriz insumo-produto a partir de dados preliminares das contas nacionais. Economia Aplicada, v. 9, n. 2, p. 277299, 2005.

GURGEL, A. C. Impactos da Liberalização Comercial de Produtos do Agronegócio na Rodada de Doha. Revista Brasileira de Economia, São Paulo, v. 60, n. 2, p. 133-151, 2006.

Impactos de políticas comerciais e agrícolas sobre a agropecuária e agroindústria brasileiras. In: Anais do $52^{\circ}$ Congresso da Sociedade Brasileira de Economia e Sociologia Rural, Goiânia, 2014.

GURGEL, A. C. et al. Impactos dos acordos internacionais sobre as exportações das cooperativas agropecuárias brasileiras. Revista de Economia e Sociologia Rural, v. 47, n. 4, p. 971-993, 2009.
GURGEL, A. C. e CAMPOS, A. C. Impactos da ALCA sobre o agronegócio brasileiro na presença de economias de escala e competição imperfeita. Pesquisa e Planejamento Econômico, Rio de Janeiro, v. 33, n. 3, p. 435-480, 2003.

HARRISON, W. J. e PEARSON, K. R. An Introduction to GEMPACK. GEMPACK user documentation GPD1. Melbourne: Centre of Policy Studies and IMPACT Centre, Monash University, 2002.

HORRIDGE, M. ORANI-G: A General Equilibrium Model of the Australian Economy. CoPS/IMPACT, Centre of Policy Studies, Victoria University, 2000. (Working Paper Number OP-93)

IBGE - Instituto Brasileiro de Geografia e Estatística. Matriz de Insumo-Produto: Brasil 2000-2005. Contas Nacionais, n. 23, Rio de Janeiro: IBGE, 2008.

. Sistema de Contas Nacionais: Brasil referência 2010-2011. Contas Nacionais, n. 44, Rio de Janeiro: IBGE, 2015.

JOHANSEN, L. A Multisectoral Model of Economic Growth. Amsterdam: North-Holland, 1960.

MARTINEZ, T. S. Estimação das tabelas auxiliares de impostos e margens da matriz de insumo-produto com mínima perda de informação: algoritmo RAWS. Pesquisa e Planejamento Econômico, v. 44, n. 2, p. 289-336, 2014a.

MARTINEZ, T. S. Método RAWS/RAW para estimação anual da matriz de insumo-produto na referência 2000 das contas nacionais. Brasília: IPEA, 2015. (Texto para discussão n. 2043)

MARTINEZ, T. S. Método RAWS/RAW para estimação anual da matriz de insumo-produto. Brasília: IPEA, 2014b. (Nota técnica n. 17)

OMC, Organização Mundial do Comércio (World Trade Organization - WTO). The WTO and preferential trade agreements: From co-existence to coherence. World Trade Report. Geneva, 2011. Disponível em: <www. wto.org > . Acesso em: 14 mai. 2015.

SANTOS, C. V. e FERREIRA FILHO, J. B. S. Efeitos potenciais da política tributária sobre o consumo de alimentos e insumos agropecuários: uma análise de equilíbrio geral interregional. Revista de Economia $e$ Sociologia Rural, v. 45, n. 4, p. 921-962, 2007.

SILVA, O. M. Comércio Internacional e Protecionismo Agrícola. In: SANTOS, M. L. e VIEIRA, W. C. (ed.). Agricultura na virada do milênio: velhos e novos desafios. Universidade Federal de Viçosa (UFV): Viçosa, 2000, p. 283-302. 
Apêndice A. Os 128 produtos do modelo LATES-BR

\begin{tabular}{|c|c|}
\hline Código do Produto & Descrição do Produto \\
\hline 01911 & Arroz, trigo e outros cereais \\
\hline 01912 & Milho em grão \\
\hline 01913 & Algodão herbáceo, outras fibras da lav. temporária \\
\hline 01914 & Cana-de-açúcar \\
\hline 01915 & Soja em grão \\
\hline 01916 & Outros produtos e serviços da lavoura temporária \\
\hline 01917 & Laranja \\
\hline 01918 & Café em grão \\
\hline 01919 & Outros produtos da lavoura permanente \\
\hline 01921 & Bovinos e outros animais vivos, prods. animal, caça e serv. \\
\hline 01922 & Leite de vaca e de outros animais \\
\hline 01923 & Suínos \\
\hline 01924 & Aves e ovos \\
\hline 02801 & Produtos da exploração florestal e da silvicultura \\
\hline 02802 & Pesca e aquicultura (peixe, crustáceos e moluscos) \\
\hline 05801 & Carvão mineral \\
\hline 05802 & Minerais não-metálicos \\
\hline 06801 & Petróleo, gás natural e serviços de apoio \\
\hline 07911 & Minério de ferro \\
\hline 07921 & Minerais metálicos não-ferrosos \\
\hline 10911 & Carne de bovinos e outros prod. de carne \\
\hline 10912 & Carne de suíno \\
\hline 10913 & Carne de aves \\
\hline 10914 & Pescado industrializado \\
\hline 10915 & Leite resfriado, esterilizado e pasteurizado \\
\hline 10916 & Outros produtos do laticínio \\
\hline 10921 & Açúcar \\
\hline 10931 & Conservas de frutas, legumes, outros vegetais e sucos de frutas \\
\hline 10932 & Óleos e gorduras vegetais e animais \\
\hline 10933 & Café beneficiado \\
\hline 10934 & Arroz beneficiado e produtos derivados do arroz \\
\hline 10935 & Produtos derivados do trigo, mandioca ou milho \\
\hline 10936 & Rações balanceadas para animais \\
\hline 10937 & Outros produtos alimentares \\
\hline 11001 & Bebidas \\
\hline 12001 & Produtos do fumo \\
\hline 13001 & Fios e fibras têxteis beneficiadas \\
\hline 13002 & Tecidos \\
\hline 13003 & Art. têxteis de uso doméstico e outros têxteis \\
\hline 14001 & Artigos do vestuário e acessórios \\
\hline 15001 & Calçados e artefatos de couro \\
\hline 16001 & Produtos de madeira, exclusive móveis \\
\hline 17001 & Celulose \\
\hline 17002 & Papel, papelão, embalagens e artefatos de papel \\
\hline 18001 & Serviços de impressão e reprodução \\
\hline 19911 & Combustíveis para aviação \\
\hline 19912 & Gasoálcool \\
\hline 19913 & Naftas para petroquímica \\
\hline 19914 & Óleo combustível \\
\hline
\end{tabular}


364 - Impactos Econômicos do Aumento das Exportações Brasileiras de Produtos Agrícolas e Agroindustriais para Diferentes Destinos

\begin{tabular}{|c|c|}
\hline Código do Produto & Descrição do Produto \\
\hline 19915 & Diesel - biodiesel \\
\hline 19916 & Outros produtos do refino do petróleo \\
\hline 19921 & Etanol e outros biocombustíveis \\
\hline 20911 & Produtos químicos inorgânicos \\
\hline 20912 & Adubos e fertilizantes \\
\hline 20913 & Produtos químicos orgânicos \\
\hline 20914 & Resinas,elastômeros e fibras artif. e sintéticas \\
\hline 20921 & Defensivos agrícolas e desinfestantes domissanitários \\
\hline 20922 & Produtos químicos diversos \\
\hline 20923 & Tintas, vernizes, esmaltes e lacas \\
\hline 20931 & Perfumaria, sabões e artigos de limpeza \\
\hline 21001 & Produtos farmacêuticos \\
\hline 22001 & Artigos de borracha \\
\hline 22002 & Artigos de plástico \\
\hline 23001 & Cimento \\
\hline 23002 & Artefatos de cimento, gesso e semelhantes \\
\hline 23003 & Vidros, cerâmicos e outros prod. de minerais não-metálicos \\
\hline 24911 & Ferro-gusa e ferroligas \\
\hline 24912 & Semi-acabacados, laminados planos, longos e tubos de aço \\
\hline 24921 & Produtos da metalurgia de metais não-ferrosos \\
\hline 24922 & Peças fundidas de aço e de metais não ferrosos \\
\hline 25001 & Produtos de metal, excl. máquinas e equipamentos \\
\hline 26001 & Componentes eletrônicos \\
\hline 26002 & Máquinas para escritório e equip. de informática \\
\hline 26003 & Material eletrônico e equip. de comunicações \\
\hline 26004 & Equip. de medida, teste e controle, ópticos e eletromédicos \\
\hline 27001 & Máquinas, aparelhos e materiais elétricos \\
\hline 27002 & Eletrodomésticos \\
\hline 28001 & Tratores e outras máquinas agrícolas \\
\hline 28002 & Máquinas para a extração mineral e a construção \\
\hline 28003 & Outras máquinas e equipamentos mecânicos \\
\hline 29911 & Automóveis, camionetas e utilitários \\
\hline 29912 & Caminhões e ônibus, incl. cabines, carrocerias e reboques \\
\hline 29921 & Peças e acessórios para veículos automotores \\
\hline 30001 & Aeronaves, embarcações e outros equipamentos de transporte \\
\hline 31801 & Móveis \\
\hline 31802 & Produtos de industrias diversas \\
\hline 33001 & Manutenção, reparação e instalação de máquinas e equipamentos \\
\hline 35001 & Eletricidade, gás e outras utilidades \\
\hline 36801 & Água, esgoto, reciclagem e gestão de resíduos \\
\hline 41801 & Edificações \\
\hline 41802 & Obras de infra-estrutura \\
\hline 41803 & Serviços especializados para construção \\
\hline 45001 & Comércio e reparação de veículos \\
\hline 46801 & Comércio por atacado e a varejo, exceto veículos automotores \\
\hline 49001 & Transporte terrestre de carga \\
\hline 49002 & Transporte terrestre de passageiros \\
\hline 50001 & Transporte aquaviário \\
\hline 51001 & Transporte aéreo \\
\hline 52801 & Armazenamento e serviços auxiliares aos transportes \\
\hline 52802 & Correio e outros serviços de entrega \\
\hline 55001 & Serviços de alojamento em hotéis e similares \\
\hline 56001 & Serviços de alimentação \\
\hline
\end{tabular}




\begin{tabular}{|c|c|}
\hline Código do Produto & Descrição do Produto \\
\hline 58001 & Livros, jornais e revistas \\
\hline 59801 & Serviços cinematográficos, música, rádio e televisão \\
\hline 61001 & Telecomunicações, TV por assinatura e outros serv. relacionados \\
\hline 62801 & Desenvolvimento de sistemas e outros serviços de informação \\
\hline 64801 & Intermediação financeira, seguros e previdência complementar \\
\hline 68001 & Aluguel efetivo e serviços imobiliários \\
\hline 68002 & Aluguel imputado \\
\hline 69801 & Serviços jurídicos, contabilidade e consultoria \\
\hline 71801 & Pesquisa e desenvolvimento \\
\hline 71802 & Serviços de arquitetura e engenharia \\
\hline 73801 & Publicidade e outros serviços técnicos \\
\hline 77001 & Aluguéis não-imob. e gestão de ativos de propriedade intelectual \\
\hline 78801 & Condomínios e serviços para edifícios \\
\hline 78802 & Outros serviços administrativos \\
\hline 80001 & Serviços de vigilância, segurança e investigação \\
\hline 84001 & Serviços coletivos da administração pública \\
\hline 84002 & Serviços de previdência e assistência social \\
\hline 85911 & Educação pública \\
\hline 85921 & Educação privada \\
\hline 86911 & Saúde pública \\
\hline 86921 & Saúde privada \\
\hline 90801 & Serviços de artes, cultura, esporte e recreação \\
\hline 94801 & Organizações patronais, sindicais e outros serviços associativos \\
\hline 94802 & Manutenção de computadores, telefones e objetos domésticos \\
\hline 94803 & Serviços pessoais \\
\hline 97001 & Serviços domésticos \\
\hline
\end{tabular}

Nota: Em cinza claro estão as commodities agrícolas e, em cinza escuro, os produtos agroindustriais.

Fonte: Elaboração própria. 
